Altun, D. (2018). Pre-Service Preschool Teachers' Reading Habits, Attitudes, and Experiences as Predictors of Their Level of Competence in Selecting Children's Illustrated Storybooks. Bartın University Journal of Faculty of Education, 7(3), 826-852

\begin{tabular}{l} 
Pre-Service Pres \\
Experiences as Pred \\
Article Info \\
\hline DOI: $10.14686 /$ buefad.387732 \\
\hline Article History: \\
Received $\quad 01.02 .2018$ \\
Accepted $\quad 15.07 .2018$ \\
Published $\quad 31.10 .2018$ \\
\hline Keywords: \\
Illustrated storybooks \\
Pre-service \\
Preschool teacher \\
Reading attitude \\
Reading habits \\
\hline Article Type: Research Article \\
\hline
\end{tabular}

Bartın University Journal of Faculty of Education, 7(3), 826-852

Bartın Üniversitesi Eğitim Fakültesi Dergisi, 7(3), 826-852

buefad.bartin.edu.tr

Pre-Service Preschool Teachers' Reading Habits, Attitudes, and Children's Illustrated Storybooks

Dilek ALTUN*a

\begin{tabular}{|c|c|}
\hline \multicolumn{2}{|c|}{$\begin{array}{c}\text { Okul Öncesi Öğretmen Adaylarının Okuma Alışkanlıkları, Tutumları ve } \\
\text { Deneyimlerinin Resimli Hikâye Kitabı Seçme Yeterliliklerini Yordama } \\
\text { Düzeyi }\end{array}$} \\
\hline Makale Bilgisi & $\ddot{\mathbf{O ̈ z}}$ \\
\hline DOI: $10.14686 /$ buefad.387732 & $\begin{array}{l}\text { Hikâye dinleme ve okuma, çocukların hem ev içi hem de okul öncesi eğitim } \\
\text { kurumlarında gelişimlerinin eğlenerek desteklendiği önemli etkinliklerden biridir. }\end{array}$ \\
\hline Makale Geçmişi: & Çocuklara sunulacak zengin içerikte, kaliteli çocuk kitapları çocukların gelişimlerini \\
\hline Geliş & desteklemek adına büyük önem taşımaktadır. Bu nedenle, okul öncesi öğretmenlerinin \\
\hline Kabul & piyasada yayınlanan kitaplar arasından çocukların gelişim düzeylerine uygun kitapları \\
\hline Yayın $\quad 31.10 .2018$ & seçmeleri önem taşımaktadır. Öğretmen adaylarının okuma tutumları ve \\
\hline $\begin{array}{l}\text { Anahtar Kelimeler: } \\
\text { Resimli hikâye kitabı } \\
\text { Öğretmen adayı, } \\
\text { Okul öncesi } \\
\text { Okuma tutum } \\
\text { Okuma alıșkanlığı }\end{array}$ & $\begin{array}{l}\text { alışkanlıklarına bağlı olarak kitaplar hakkında kazandıkları deneyimlerin resimli } \\
\text { çocuk kitapları seçme yeterlilikleri üzerine etkisi olabileceği düşünülmektedir. Bu } \\
\text { çalışma kapsamında okul öncesi öğretmen adaylarının kişisel okuma kültür ve } \\
\text { deneyimlerinin resimli çocuk kitabı seçme yeterlilikleri olan ilişkisinin incelemesi } \\
\text { hedeflenmiştir. Çalışmanın katılımcıları } 213 \text { (kadın: 172, erkek: 41) okul öncesi } \\
\text { öğretmen adayıdır. Çalışmanın verileri ölçek ve demografik bilgi formu kullanılarak }\end{array}$ \\
\hline $\begin{array}{l}\text { Makale Türü: Araştırn } \\
\text { Makalesi }\end{array}$ & $\begin{array}{l}\text { toplanmıştır. Araştırma sonuçlarına göre, öğretmen adaylarının kişisel okuma } \\
\text { alışkanlıkları, okuma tutumları, üniversite eğitimleri boyunca okudukları çocuk kitabı } \\
\text { sayısı ve çocuk edebiyatı dersi almaları ile resimli hikâye kitabı seçme yeterlilikleri } \\
\text { arasında anlamlı ilişki bulunmaktadır. }\end{array}$ \\
\hline
\end{tabular}

\begin{abstract}
Listening to and reading stories are important activities for children's development, and they can be supported in pleasant ways both at home and at preschool institutions. Thus, quality children's books with rich content are important for supporting preschoolers' development. Therefore, it is important for preschool teachers to choose books that are appropriate for the development level of children. It is thought that the book experiences of the pre-service teachers depend on their reading attitudes and that their habits may influence their competence when selecting picture books for children. This study aimed to examine the relationship between pre-service teachers' personal reading culture and experiences and their competence in selecting picture books for children. Participants of the study totaled 213 (female, 172; male, 41) pre-service preschool teachers. The results of the study revealed that there is a significant relationship between pre-service teachers' personal reading habits, reading attitudes, the number of children's books they read during their university education, and the children's literature courses they take at the university and their competence in selecting children's picture books.
\end{abstract} arasında anlamlı ilişki bulunmaktadır.

\footnotetext{
*Corresponding Author: daltun@ahievran.edu.tr Assist. Prof. Dr., Ahi Evran University, Kırşehir/Turkey, https://orcid.org/0000-0002-9973-0585
} 


\section{Introduction}

Listening to and reading stories are important activities that support children's development both at home and at preschool institutions. Research has revealed that stories read and told to children contribute to their development in many areas, such as listening comprehension, narrative skills, vocabulary acquisition, print awareness, prosocial behaviors, and mathematical skills (Altun, 2016; Bus, van Ijzendoorn, \& Pellegrini, 1995; Flack, Field, \& Horst, 2017; Hepburn, Egan, \& Flynn, 2010; Uzmen \& Mağden, 2002). Picture books provide a context for children to be exposed to many concepts and topics, enabling the acquisition of these concepts during their early childhood education programs (Ulusoy \& Altun, 2017). In addition, regular and interesting book reading activities provided to children early on can contribute to positive attitudes about reading (Altun, 2013). International literature notes the number of books available at home and in preschool classes as an important indicator of the literacy environment and scholarly culture (Evans, Kelley, \& Sikora, 2014; Evans, Kelley, Sikora, \& Treiman, 2010; Smith, Brady, \& Anastasopoulos, 2008). Therefore, quality children's books with rich content are of great importance in supporting children's development.

\section{Children's Picture Books}

A children's picture book is a comprehensive, "umbrella term" that describes books that are prepared with various content and in various formats that are appropriate for the developmental levels of children (Kiefer, Hepler, \& Hickman, 2007). The main types of children's picture books are toy books, ABC books, concept books, activity books, counting books, wordless books, guessing books, and illustrated storybooks (Kiefer, et al., 2007; Ural, 2015). Illustrated storybooks support the story with visuals, making it easier for children to follow the story using visual reading, enabling them to have fun while learning by attracting and holding their attention. By focusing on children's picture books in the process of how children build meaning, Painter, Martin, and Unsworth (2013) discussed how visuals in children's books (inside and around text/pertextuality) are interpreted by children in the context of semiotics. Studies that examined children's visual narratives about stories show that children benefit from visuals in the process of story comprehension during story reading and in the process of narrating the text after reading it (Arizpe \& Styles, 2004; Ulusoy \& Altun, 2016; 2017).

Guijarro (2014) argued that it is important to select books of the appropriate level for children to increase their interactions with illustrated storybooks. Illustrated children's books should have topics and a narrative appropriate to the child's developmental levels; they should also be appropriate for the child's developmental levels in terms of their physical design, formatting, and illustrations. Guijarro (2014) dealt with children's books under two headings that followed Piaget's cognitive development stages. These are the books that should be prepared for the children in the sensory-motor stage and in the preoperational stage. Kiefer et al. (2007, pp. 44-55) considered the books according to the age and development of children and put them under six headings. These headings are as follows: a) infancy ( $0-3$ years), b) preschool and kindergarten (3-5 years), c) primary ages 6 and 7, d) middle elementary ( $8-9$ years), later elementary (10-11 years), and f) middle school (12-14 years). According to Kiefer et al.'s (2007, s. 44-55) classification, early childhood books are separated into two groups: 0-3 years and 3-5 years. Gönen, Uludağ, Fındık-Tanrıbuyurdu, and Tüfekçi (2014) stated that preschool children's books can be separated into two groups: 0-3 years and 3-6 years. Likewise, Yükselen (2017) placed children's books into three groups: 0-3 years, 4-6, and 7-9 years. According to Kiefer et al. (2007), children have short attention spans; thus, it is recommended that the books for preschool children ( $0-3$ years) have few pages, plenty of pictures, and little text. These books can include objects children see around them, activities (eating, dressing, etc.), living things, and family members. In addition, topics such as compassion, love, and friendship could enable children to build trust in their relationships with family members and other people who are important to them. Short dialogues and rhyming words are preferred because they could attract children's attention and support their language development. It is suggested that books should be light enough for children to lift and hold comfortably, their pages thick enough for children to turn easily, and be appealing to children's tactile senses (Gönen et al., 2014; Gönen, Burçak, Uysal, \& Bediz, 2017; Kiefer et al., 2007; Yükselen, 2017).

Depending on the development in children's language and their psychomotor, socio-emotional, and cognitive areas, the books prepared for the 3-6 age group should have different characteristics than those for the 0-3 age group (Guijarro, 2014; Kiefer et al., 2007). The books should include topics to support the increasing imagination 
of children, enabling them to learn about new topics and concepts. In addition, it is suggested that the books should include different topics that encourage children to reflect on their feelings through the stories (happiness, sadness, darkness, fear of leaving their mother, new siblings, etc.) (Kiefer et al., 2007; Yükselen, 2017). With increasing cognitive skills, concepts such as before, now, and after that enable children to put the events in chronological order can be included in the books (Yükselen, 2017). Because children are egocentric during this period, it is important to include characters with which the children can identify. Kiefer et al. (2007) pointed out that it is important to create impressive and powerful story characters that will take root in the children's memories. Further, it is emphasized that books that cause children to create stereotypes (race and gender) through content and characters should be avoided (Çatalcalı-Soyer, 2009; Kiefer et al., 2007).

Although the related literature emphasizes the properties that the books should have according to the children's developmental levels, studies have indicated that the current published children's books present some problems in terms of their contents and format features (Çatalcalı-Soyer, 2009; Dağlığlu \& Çamlıbel-Çakmak, 2009; Veziroğlu \& Gönen, 2012). Dağlığlu and Çamlıbel-Çakmak (2009) examined 174 preschool-level storybooks, looking for themes of violence and fear. They showed that the $8 \%$ of the books contained violence, and $11 \%$ of the books contained elements of fear. In the 50 children's books that Çatalcal1-Soyer (2009) examined, stereotypes were revealed in respect to gender, family (modern-traditional), and community structure (urban-rural). Veziroğlu and Gönen (2012) studied 250 illustrated children's books for their appropriateness for the achievements outlined in the 2006 Preschool Education Program. The illustrated children's books considered in the study covered only $18.5 \%$ of the 264 expected acquisitions included in the 2006 program. Therefore, it is important for preschool teachers to choose books that are appropriate for the level of development of children. Within the scope of a children's literature course, pre-service teachers receive theoretical information regarding children's literature, and sample books appropriate for children's developmental levels are shared. In addition to the education they receive within the scope of the children's literature course, it is thought that pre-service teachers' personal reading habits, experiences, and attitudes can be effective in creating a reading culture and selecting the appropriate books for their students.

\section{Pre-service Teachers' Reading Habits and Attitudes toward Reading}

Studies have indicated that pre-service teachers have limited or undeveloped reading habits (Gür, 2014; Odabaş, Odabaş, \& Polat, 2008; Sağlam, Suna, \& Çengelci, 2007; Saraçoğlu, Karasakaloğlu, \& Aslantürk, 2010;) and reading attitudes (Dedeoğlu \& Ulusoy, 2013; Saraçoğlu, et al., 2010). A large number of studies carried out with various participant groups, such as teachers, pre-service teachers, family members, and students (Bayram, 2001; Karaşahin, 2009; Konan, 2013; Kuş \& Türkyılmaz, 2010; Mavi \& Çetin, 2009; Şengül-Bircan, 2017; Y1lmaz, 2002) have shown that "illiterate literates" (Huck, 1973) are common in Turkey.

According to McKenna's (1994) reading attitude model, the attitudes of individuals toward reading are influenced by both the cultural context and social environment (McKenna, Kear, \& Elisworth, 1995). There is a relationship between children's home literacy environments and their reading attitudes during the preschool period (Altun, 2013). The studies have shown that there is a relationship between the individual's attitude toward reading, his or her reading habits, and his or her reading comprehension (Baccus, 2004; Kırmız1, 2011; Petscher, 2010; Progress in International Reading Literacy Study (PIRLS), 2011; Sallabaş, 2008; Sonleitner, 2005). Individuals develop an attitude toward reading based on their reading experience and organize their reading experiences according to their reading attitude. It is thought that the book experiences of the pre-service teachers, depending on their reading attitudes and habits, may have an influence on their competence in selecting illustrated children's books for preschool students. The current study aimed to examine the relationship between pre-service teachers' personal reading cultures and experiences and their competence in selecting picture books for children. With this goal in mind, this study sought answers to the following questions:

1) Is there a significant difference between pre-service preschool teachers' competence levels when it comes to selecting illustrated children's books according to whether or not they took a children's literature course at university? 
2) Is there a significant difference between pre-service preschool teachers' competence levels when it comes to selecting illustrated children's books according to how often their parents read books to them in their childhood?

3) Is there a significant difference between pre-service preschool teachers' reading attitude scores according to how often their parents read books to them in their childhood?

4) To what extent do pre-service preschool teachers' personal reading habits, attitudes, and experiences predict their competence in selecting illustrated children's books?

\section{Method}

\section{Research Design}

A cross-sectional correlational research design was used in the current study to investigate the relationship between pre-service preschool teachers' competence in selecting illustrated children's books and their personal reading habits, attitudes, and experiences.

\section{Study Group}

There were 213 participants in the study (female, 172; male, 41), including pre-service teachers who were enrolled at the Department of Preschool Education at a state university in the fall semester of the 2017-2018 academic year. The participants of the study were selected using an appropriate sampling method. Detailed information about the pre-service teachers who participated in the study is given in Table 1.

$\underline{\text { Table 1. Demographic Information of the Pre-service Preschool Teachers }}$

\begin{tabular}{lcc}
\hline & $f$ & $\%$ \\
\hline Gender & 172 & 80.8 \\
Female & 41 & 19.2 \\
Male & 213 & 100 \\
Total & & \\
\hline Year & 59 & 27.7 \\
Freshmen & 46 & 21.6 \\
Sophomore & 57 & 26.8 \\
Junior & 51 & 23.9 \\
Senior & 213 & 100 \\
Total & & \\
\hline Took children's literature course & 122 & 57.3 \\
Yes & 91 & 42.7 \\
No & 213 & 100 \\
Total & & \\
\hline How often their parents read to them in their & & \\
childhood & 111 & 52.1 \\
Never & 41 & 19.2 \\
Once a month & 39 & 18.3 \\
Once a week & 22 & 10.3 \\
Every day & 213 & 100 \\
Total & & \\
\hline
\end{tabular}

The participants consisted of 59 freshmen (27.7\%), 46 sophomores (21.6\%), 57 juniors (26.8\%), and 51 seniors (23.9\%). Most $(57.3 \%)$ of the pre-service teachers took the children's literature course, which is a compulsory course offered in the second spring semester. A total of 17 of the pre-service teachers were either in their second university year or vertical transfer students. Those students who were lateral transfers in their first or second year had taken the children's literature course at their previous university. 
The responses of the pre-service teachers revealed that $52.1 \%$ of their parents never read books to them during their childhood. However, $10.3 \%$ of the pre-service teachers stated that their parents read to them on a daily basis.

\section{Data Collection Tools}

The data of the study were collected using the Examination of Level of Competency in Choosing Picture Storybooks and Perception of Self Competency of Early Childhood Education Teacher Candidates (Turan, Gönen, \& Aydos, 2017), the Mikulecky Behavioral Reading Attitude Scale (Dedeoğlu \& Ulusoy, 2013), and the demographic information form.

\section{Examination of Level of Competency in Choosing Picture Storybooks and Perception of Self Competency of Early Childhood Education Teacher Candidates}

The form was developed to assess the pre-service teachers' self-efficacy of children's book selecting competence levels. The form consists of three parts: content, illustration, and physical features (Turan et al., 2017). There are a total of 59 items in the form of a 5-point Likert scale that ranges from insufficient to very good. The physical features component has 10 items, the content component contains 28 items, and the illustration component has 21 items (Turan et al., 2017). After applying this form to 213 pre-service teachers, the Cronbach alpha values were calculated for each sub-dimension of the form. The Cronbach alpha value was found to be .84 for the physical properties subscale, .91 for the content subscale, and .82 for the illustration subscale.

\section{Mikulecky Behavioral Reading Attitude Scale}

The scale was developed by Mikulecky (1976) to measure adults' attitudes toward reading. The scale consists of 20 items in a 5-point Likert type scale that ranges from not for me at all to just for me. The items in the scale were prepared in accordance with the five steps of Krathwohl's Affective Area Taxonomy: a) awareness of reading, b) positive approach to reading, c) regarding reading as an important value, d) reading as an organized activity, and e) reading as a part of personality (Dedeoglu \& Ulusoy, 2013, p. 82; Richardson, Morgan, \& Fleener, 2009, p. 477). The scale was adapted into Turkish by Dedeoğlu and Ulusoy (2013). In his work with pre-service teachers, Warmack (2007) calculated the Cronbach alpha value of the scale to be .92. In the pilot study conducted with 120 pre-service primary teachers during the adaptation of the scale to the Turkish language, the Cronbach alpha value was .86 (Dedeoğlu \& Ulusoy, 2013). The Cronbach alpha value for the current study was .88.

\section{Demographic Information Form}

The demographic information of pre-service teachers was collected by using the form. This information included gender, class level, whether or not they had taken the children's literature course, how often their parents read to them during their childhood, how much time they spent reading each week, and the number of books they had read over the last year.

\section{Data Collection Procedures}

In the fall semester of the 2017-2018 academic year, the data collection instruments were distributed to the pre-service teachers in the classroom environment, and they were asked to read the questions carefully and complete all the questions. The duration of implementation of the questionnaires took approximately 35 minutes.

\section{Data Analysis}

The data obtained in the study were transferred to the SPSS Statistics ver. 22.00 software program and analyzed using descriptive and inferential statistical methods (independent samples t-test, one-way ANOVA, Pearson correlation, and multiple regression). 


\section{Findings}

Prior to presenting inferential statistical analyses, the distributions of the data set are shown in Table 2. When examining the skewness and kurtosis values related to the data sets, it was found that the values showed a normal distribution because they were within the normal range $(-2,+2)$ (Tabachnick \& Fidell, 2007). Furthermore, histogram graphs also supported the normal distribution of the scores.

Pre-service teachers' weekly reading time ranged from 0 to $250 \mathrm{~min}$. Some (19) of the pre-service teachers stated that they never read books. The average weekly reading time of the pre-service teachers was $117.10(S D=$ 17.85). The average number of children's books read by pre-service teachers during their university education was $8.51(S D=3.92)$. The average number of books read by the pre-service teachers in the last year was $6.21(S D=$ 2.90).

Table 2. Descriptive Statistics for the Data Set

\begin{tabular}{lccccccc}
\hline Variables & $\boldsymbol{n}$ & Min. & Max. & $\boldsymbol{M}$ & $\boldsymbol{S D}$ & Skewness & Kurtosis \\
\hline $\begin{array}{l}\text { Competence in selecting } \\
\text { illustrated children's books }\end{array}$ & & & & & & & \\
Physical properties & 213 & 30 & 50 & 45.03 & 4.26 & -.73 & .180 \\
Content properties & 213 & 78 & 140 & 123.78 & 9.90 & -1.12 & 1.26 \\
Illustration properties & 213 & 75 & 105 & 97.66 & 7.74 & -.05 & .20 \\
\hline Reading attitude & 213 & 33 & 100 & 77.84 & 12.47 & -.612 & .25 \\
\hline Weekly reading time (min) & 213 & 0 & 250 & 117.10 & 17.85 & 1.145 & .40 \\
\hline $\begin{array}{l}\text { Number of children's books read } \\
\text { during university education }\end{array}$ & 213 & 0 & 25 & 8.51 & 3.92 & 1.60 & 1.72 \\
\hline $\begin{array}{l}\text { Number of books read in the last } \\
\text { year }\end{array}$ & 213 & 0 & 20 & 6.21 & 2.90 & 1.74 & 1.87 \\
\hline
\end{tabular}

Pre-service Teachers' Levels of Competence in Selecting Illustrated Children's Books Based on Whether or Not They Had Taken a Children's Literature Course

To examine whether the scores of the pre-service teachers in selecting children's books show a significant difference according to the variable of whether they had taken the children's literature course, an independentsamples t-test was applied. According to the results of the Levene variance test, the variances of the physical properties, content, and illustration scores among the groups that had and had not taken the children's literature course were homogeneous $(p>.05)$; the reading attitude scores of the pre-service teachers between the groups were also homogenous (Pallant, 2010).

A significant difference was found in favor of those who had taken the children's literature course in terms of their competence in selecting illustrated children's books when it came to the book's physical properties, $t(211)=$ $3.441, \mathrm{p}<.05$. The effect size for the difference between the groups was shown to be small $\left(\eta^{2}=.05\right)$.

Table 3. Independent Samples t-test Results of Pre-service Teachers' Scores of Competence in Selecting Illustrated Children's Books According to Whether They Had Taken a Children's Literature Course

\begin{tabular}{|c|c|c|c|c|c|c|c|}
\hline & & $n$ & $M$ & $S D$ & $t$ & $p$ & $\eta^{2}$ \\
\hline \multicolumn{8}{|c|}{$\begin{array}{l}\text { Competence in selecting illustrated } \\
\text { children's books }\end{array}$} \\
\hline \multirow[t]{2}{*}{ Physical properties } & Yes & 122 & 45.88 & 4.12 & 3.441 & .001 & .053 \\
\hline & No & 91 & 43.10 & 4.34 & & & \\
\hline Content properties & Yes & 122 & 126.10 & 9.56 & 3.010 & .003 & .041 \\
\hline
\end{tabular}




\begin{tabular}{lccccccc} 
& No & 91 & 120.69 & 10.24 & & & \\
\hline Illustration & Yes & 122 & 99.40 & 9.90 & 3.715 & .000 & .061 \\
properties & No & 91 & 95.45 & 8.85 & & & \\
\hline
\end{tabular}

Table 3 shows a significant difference was found in the competence scores of pre-service teachers when it came to selecting illustrated children's books in terms of content; those who took a children's literature course showed a better aptitude in doing so, $t(211)=3.010, p<.05$. The effect size related to the difference was shown to have a small $\left(\eta^{2}=.04\right)$.

A significant difference was found in the competence scores of pre-service teachers when it came to selecting illustrated children's books in terms of the illustration properties; here, again, those who took a children's literature course showed a better aptitude in doing so, $t(211)=3.715, p<.05)$. The difference between the groups was found to be of moderate effect size $(\eta 2=.06)$. Detailed information is given in Table 3.

\section{Pre-service Teachers' Levels of Competence in Selecting Illustrated Children's Books Based on the Frequency Their Parents Had Read to Them in Their Childhood}

To examine whether the scores of the pre-service teachers in the form of competence in selecting children's books show a significant difference according to the variable of the frequency their parents reading to them in their childhood, a one-way ANOVA was conducted. The Levene variance test results were examined for the subscales of illustrated children's books selecting competence forms, and variances $(p>.05)$ between the groups were found to be homogeneous (Pallant, 2010).

According to the results of one-way ANOVA, there was no significant difference in the scores obtained by pre-service preschool teachers for competence in selecting illustrated children's books in terms of physical properties according to the frequency their parents read books to them in their childhood, $F(3,209)=2.112, p>$ $.05, \eta 2=.03)$.

Table 4. Pre-service Teachers' Levels of Competence in Selecting Illustrated Children's Books in Terms of Physical Properties Based on the Frequency Their Parents Had Read Books to Them in Their Childhood

\begin{tabular}{lcccccc}
\hline $\begin{array}{l}\text { Physical } \\
\text { properties }\end{array}$ & $\begin{array}{c}\text { Sum of } \\
\text { Squares }\end{array}$ & SD & $\begin{array}{c}\text { Mean } \\
\text { Square }\end{array}$ & $\boldsymbol{F}$ & $\boldsymbol{p}$ & $\boldsymbol{\eta}^{\mathbf{2}}$ \\
\hline Between groups & 113.610 & 3 & 37.870 & 2.112 & .10 & .029 \\
Within groups & 3748.089 & 209 & 17.933 & & & \\
Total & 3861.700 & 212 & & & & \\
\hline
\end{tabular}

As shown in Table 5, there was a significant difference in the scores obtained for selecting illustrated children's books in terms of content properties according to the frequency their parents read books to them during their childhood, $\left.F(3,209)=7.283, p<.05, \eta^{2}=.09\right)$.

The Scheffe test was performed to investigate the significant difference between the groups. The results showed a significant difference between the groups for their parents had not read any books to them in their childhood ( $M$ $=121.02, S D=10.04)$ and whether they were read to them one day a week $(M=128.25 ; S D=9.17)$ or every day $(M=132.77 ; S D=8.91)$.

Table 5. Pre-service Teachers' Levels of Competence in Selecting Illustrated Children's Books in Terms of Content Properties Based on the Frequency Their Parents Had Read Books to Them in Their Childhood

\begin{tabular}{lllllll}
\hline $\begin{array}{l}\text { Content } \\
\text { properties }\end{array}$ & $\begin{array}{l}\text { Sum of } \\
\text { squares }\end{array}$ & $\boldsymbol{S D}$ & $\begin{array}{l}\text { Mean } \\
\text { Square }\end{array}$ & $\boldsymbol{F}$ & $\boldsymbol{p}$ & $\boldsymbol{\eta}^{\mathbf{2}}$ \\
\hline Between groups & 3504.835 & 3 & 1168.278 & 7.283 & .000 & .09 \\
Within groups & 33524.657 & 209 & 160.405 & & & \\
Total & 37029.493 & 212 & & & \\
\hline
\end{tabular}


According to the results of the one-way ANOVA, there was a significant difference between the scores of the pre-service preschool teachers for selecting illustrated children's books in terms of illustration properties according to the frequency with which their parents had read books to them in their childhood, $F(3,209)=4.68, p<.05, \eta^{2}$ $=.06$. The Scheffe test was performed to investigate the significant difference among the groups. The results showed a significant difference between the groups for their parents had not read any books to them in their childhood $(M=96.36, S D=8.11)$ and those who indicated that their parents had read to them every day $(M=$ $101.72, S D=7.07)$.

Table 6. Results of the One-way ANOVA of Pre-service Preschool Teachers' Competence Scores in Selecting Illustrated Children's Books in Terms of Illustration Properties According to the Frequency Their Parents Had Read to Them in Their Childhood

\begin{tabular}{lcccccc}
\hline $\begin{array}{l}\text { Illustration } \\
\text { properties }\end{array}$ & $\begin{array}{c}\text { Sum of } \\
\text { squares }\end{array}$ & $\boldsymbol{S D}$ & $\begin{array}{c}\text { Mean } \\
\text { Square }\end{array}$ & $\boldsymbol{F}$ & $\boldsymbol{p}$ & $\boldsymbol{\eta}^{\mathbf{2}}$ \\
\hline Between groups & 801.385 & 3 & 267.128 & 4.68 & .003 & .063 \\
Within groups & 11909.948 & 209 & 56.985 & & & \\
Total & 12711.333 & 212 & & & & \\
\hline
\end{tabular}

Pre-service Preschool Teachers' Attitudes toward Reading According to the Frequency That Their Parents Had Read Books to Them in Their Childhood

A one-way ANOVA was applied to examine whether pre-service teachers' reading attitudes showed any difference according to the frequency that their parents had read books to them in their childhood. According to the Levene variance test, the variance $(p>.05)$ among the groups in the reading attitude scores of the pre-service teachers was homogenous (Pallant, 2010).

Table 7. The Results of the One-way ANOVA of Pre-service Preschool Teachers' Reading Attitudes Scores According to the Frequency That Their Parents Had Read Books to Them in Their Childhood

\begin{tabular}{lcccccc}
\hline $\begin{array}{l}\text { Illustration } \\
\text { properties }\end{array}$ & $\begin{array}{c}\text { Sum of } \\
\text { Squares }\end{array}$ & $\boldsymbol{S D}$ & $\begin{array}{c}\text { Squares } \\
\text { average }\end{array}$ & $\boldsymbol{F}$ & $\boldsymbol{p}$ & $\boldsymbol{\eta}^{\mathbf{2}}$ \\
\hline Inter-group & 4700.595 & 3 & 1566.865 & 11,574 & .000 & .142 \\
Intra-group & 28293.977 & 209 & 135.378 & & & \\
Total & 32994.573 & 212 & & & & \\
\hline
\end{tabular}

According to the results of the one-way ANOVA, there was a significant difference in the scores of pre-service preschool teachers for the reading attitude scale according to the frequency that their parents had read books to them in their childhood, $F(3,209)=11.57, p<.05, \eta^{2}=.14$. The Scheffe test was applied to investigate the significant difference among the groups. According to the Scheffe test results, there was a significant difference between the groups that stated that their parents had never read books to them in their childhood $(M=74.018, S D$ $=11.79)$ and had read books to them one day a week $(M=83.74, S D=12.07)$ or every day $(M=86.68, S D=$ 11.19).

Examination of the Relationship between Pre-service Preschool Teachers' Personal Reading Habits, Attitudes, and Experiences and Their Competence in Selecting Illustrated Children's Books

To examine the relationship between pre-service preschool teachers' personal reading habits, attitudes, and experiences and their competence in selecting illustrated children's books, the Pearson correlation analysis was applied. Preliminary analyses showed that there is no violation of the assumptions of normality and linearity. According to the results of the Pearson correlation analysis, there was a strong positive relationship between the reading attitude scores of the pre-service teachers and their competence in selecting illustrated children's books in terms of content $(r=.51, p<.01)$. There was a positive moderate relationship between pre-service teachers' reading attitudes and their competence in selecting illustrated children's books in terms of illustration $(r=.45, p<.01)$ and physical properties $(r=.32, p<.01)$. Also, there was a positive moderate relationship $(r=.33, p<.01)$ between pre-service teachers' weekly reading time and their competence in selecting illustrated children's books in terms of content. 
Table 8. Bivariate Correlations between the Study Variables

\begin{tabular}{|c|c|c|c|c|c|c|c|}
\hline & 1 & 2 & 3 & 4 & 5 & 6 & 7 \\
\hline 1. Weekly reading time & - & & & & & & \\
\hline $\begin{array}{l}\text { 2. Number of books read in the last } \\
\text { year }\end{array}$ & $.59 * *$ & - & & & & & \\
\hline $\begin{array}{l}\text { 3. Number of children's books read } \\
\text { during university education }\end{array}$ & $.26 * *$ & $.27 * *$ & - & & & & \\
\hline $\begin{array}{l}\text { 4. Illustrated children's book } \\
\text { content properties }\end{array}$ & $.33 * *$ & $.30 * *$ & $.25 * *$ & - & & & \\
\hline $\begin{array}{l}\text { 5. Illustrated children's book } \\
\text { Illustration }\end{array}$ & .10 & $.18 * *$ & $.24 * *$ & $.63 * *$ & - & & \\
\hline $\begin{array}{l}\text { 6. Illustrated children's book } \\
\text { physical properties }\end{array}$ & $.19^{* *}$ & $.23^{* *}$ & $.23 * *$ & $.50 * *$ & $.54 * *$ & - & \\
\hline 7. Reading attitude & $.52 * *$ & $.48 * *$ & $.18 * *$ & $.51 * *$ & $.45 * *$ & $.32 * *$ & - \\
\hline
\end{tabular}

\section{Note. $* p<.05, * * p<.01$.}

There was a positive low relationship between the number of children's books pre-service teachers had read during their university education and the content $(r=.25, p<.01)$ and physical properties $(r=.24, p<.01)$ of the books they selected. Detailed information is presented in Table 8.

\section{Examination of Pre-service Teachers' Personal Reading Habits, Attitudes, and Experiences as Predictors of Their Level of Competence in Selecting Illustrated Children's Books}

Before applying multiple regression analysis, the assumptions of the test were checked separately for all three models. The assumptions of the multiple regression analysis, sample size $(N>50+8 m, m=$ number of predictors $)$, multicollinearity, homoscedasticity, outliers, and linearity were met by the data sets. Whether pre-service teachers had taken a children's literature course was included in the analysis as a dummy variable.

Table 9. Results of Multiple Regression Analysis of Predicting the Content Properties Scores of Illustrated Children's Books

\begin{tabular}{|c|c|c|c|c|c|c|}
\hline Predictors & $\boldsymbol{B}$ & $\beta$ & $t$ & $p$ & Tolerance & $\begin{array}{c}\text { Variance inflation } \\
\text { factor (VIF) }\end{array}$ \\
\hline Constant & 81.293 & & 14.808 & .000 & & \\
\hline $\begin{array}{l}\text { Number of children's } \\
\text { books read during } \\
\text { university education }\end{array}$ & .392 & .204 & 3.020 & .003 & .687 & 1.456 \\
\hline Reading attitude & .415 & .391 & 5.852 & .000 & .700 & 1.429 \\
\hline Weekly reading time & .006 & .057 & .836 & .404 & .674 & 1.483 \\
\hline $\begin{array}{l}\text { Whether or not they took } \\
\text { children's literature course }\end{array}$ & 4.478 & .168 & 2.600 & .010 & .748 & 1.337 \\
\hline
\end{tabular}

Note. $R^{2}=.35$, corrected $R^{2}=.35, F(5,207)=27.82, p=.000$.

According to the results of the multiple regression analysis, there was a significant relationship between preservice teachers' scores for competence in selecting illustrated children's books in terms of the books' content properties and the number of children's books read during university education, their reading attitudes, and whether they took a children's literature course $(F=27.82, p<.05)$. According to the model, the predictors 
explained $35 \%$ of the total variance of the content properties' competence scores. When the standardized beta $(\beta)$ coefficients of the model were examined, the reading attitude $(\beta=.415, p<.05)$ variable was a stronger predictor than the other variables. Weekly reading time $(\beta=.006, p>.05)$ was not a significant predictor of the model. Detailed information is presented in Table 9.

Table 10. Results of the Multiple Regression Analysis for Predicting the Illustration Properties Scores of Illustrated Children's Books

\begin{tabular}{|c|c|c|c|c|c|c|}
\hline Predictors & $B$ & $\beta$ & $t$ & $p$ & Tolerance & $\begin{array}{l}\text { Variance inflation } \\
\text { factor (VIF) }\end{array}$ \\
\hline Constant & 71.560 & & 21.663 & .000 & & \\
\hline $\begin{array}{l}\text { Number of children's } \\
\text { books read during } \\
\text { university education }\end{array}$ & .212 & .188 & 2.716 & .007 & .687 & 1.456 \\
\hline Reading attitude & .277 & .447 & 6.500 & .000 & .700 & 1.429 \\
\hline Weekly reading time & -.010 & -.152 & -2.177 & .031 & .674 & 1.483 \\
\hline $\begin{array}{l}\text { Whether or not they took } \\
\text { children's literature course }\end{array}$ & 2.801 & .180 & 2.702 & .007 & .748 & 1.337 \\
\hline
\end{tabular}

Note. $\mathrm{R}^{2}=.35$, corrected $R^{2}=.31, F(5,207)=23.67, p<.05$.

A multiple regression analysis was conducted to examine the predictors of the scores for competence in selecting illustrated children's books in terms of the books' illustration properties. According to the results of the analysis, there was a significant relationship among the variables for the number of children's books read during university education, reading attitude, weekly reading time, and taking children's literature courses $(F=23.67, p$ $<.05)$. According to the model, the predictors explained $31 \%$ of the total variance of the scores for the illustration properties competence. When the standardized beta $(\beta)$ coefficients of the model were examined, the reading attitude $(\beta=.447, p<.05)$ variable was a stronger predictor than the other variables. Detailed information is presented in Table 10 .

According to the results of the multiple regression analysis, there was a significant relationship between the variables of the scores for competence in selecting illustrated children's books in terms of their illustration properties and the number of books read at university, reading attitude, and taking a children's literature course $(F$ $=13.82, p<.05)$. According to the model, the predictors explained $21 \%$ of the total variance of the content properties. When the standardized beta $(\beta)$ coefficients for the model were examined, the number of children's books $(\beta=.245, p<.05)$ read at university was shown to be a stronger predictor than the other variables. Weekly reading time $(\beta=.033, p>.05)$ was not a significant predictor of the model. Detailed information is presented in Table 11.

Table 11. Results of Multiple Regression Analysis of Predicting the Physical Properties Scores of Illustrated Children's Books

\begin{tabular}{|c|c|c|c|c|c|c|}
\hline Predictors & $B$ & $\beta$ & $t$ & $p$ & Tolerance & $\begin{array}{c}\begin{array}{c}\text { Variance inflation } \\
\text { factor (VIF) }\end{array} \\
\end{array}$ \\
\hline Constant & 36.367 & & 18.628 & .000 & & \\
\hline $\begin{array}{l}\text { Number of children's } \\
\text { books read during } \\
\text { university education }\end{array}$ & .152 & .245 & 3.300 & .001 & .687 & 1.456 \\
\hline Reading attitude & .071 & .208 & 2.821 & .005 & .700 & 1.429 \\
\hline Weekly reading time & .001 & .033 & .442 & .659 & .674 & 1.483 \\
\hline $\begin{array}{l}\text { Whether or not they took } \\
\text { children's literature course }\end{array}$ & 1.306 & .152 & 2.132 & .034 & .748 & 1.337 \\
\hline
\end{tabular}

Note. $R^{2}=.35 .21$, corrected $R^{2}=.20, F(5,207)=13.82, p<.05$. 


\section{Discussion and Conclusion}

The current study aimed to examine pre-service preschool teachers' competence in selecting illustrated children's books according to the teachers' personal reading habits, attitudes, and experiences. The findings showed that the weekly reading time of the pre-service teachers ranged from 0 to 250 minutes. Nineteen of the pre-service teachers stated that they did not read any books. Pre-service teachers were found to have limited or undeveloped reading habits. Previous studies examining the reading habits of the pre-service teachers are supported by the results of the current study (Esgin \& Karadağ, 2000; Geçgel \& Burgul, 2009; Odabaş et al., 2008; Saraçoğlu et al., 2010; Yılmaz, Köse, \& Korkut, 2009). The average annual number of books read by pre-service teachers was $6.21(S D=2.90)$. Saraçoğlu et al. $(2010)$ found that $12.9 \%$ of pre-service teachers did not read any books and that the average number of books read per month was two. In line with this and relevant to the current study, Y1lmaz et al. (2009) stated that $25 \%$ of university students did not read any books. When the average scores of the pre-service teachers' reading attitudes were examined, this score was only two points above the criterion of 75 points. In line with this, Saraçoğlu, Yenice, and Karasakaloğlu (2009) found that pre-service teachers had a moderate level of interest in reading. Dedeoğlu and Ulusoy (2013) also stated in their study that the reading attitudes of the pre-service teachers were at low to moderate levels.

A total of $52.1 \%$ of the pre-service teachers stated that their parents had not read books to them in their childhood. The percentage of pre-service teachers who indicated that their parents had read books to them regularly in their childhood was $10.3 \%$. Previous studies examining parents' habits of reading books to their children in the preschool period showed similar results (Altun, 2013; Altun \& Tantekin Erden, 2015). According Altun and Tantekin Erden (2015), the parents of 32\% of preschool children read books to their children for 0 to 60 minutes per week, and $43 \%$ of the mothers and $40 \%$ of the fathers read books weekly for 0 to 60 minutes. The findings of both this study and previous studies have revealed that there is a weak reading culture in Turkey. Although the literacy rate in Turkey has reached $96.22 \%$ (Turkey Statistics Institution [TSI], 2016), it is remarkable that the rate of regular reading habits is very low. Reading habits are gained within the family, and parents are role models for their children in this matter (Reese, Sparks, \& Leyva, 2010; Sénéchal, Lefevre, Thomas, \& Daley, 1998; Weigel, Martin, \& Bennett, 2006). For example, the campaign launched in Poland in 2001 (CałaPolskaczytadzieciom) started a nationwide book reading campaign for children. Popular artists and celebrities joined the campaign to visit kindergartens and read books to the children. In addition, through television, radio, and social media, the public was informed about the campaign, and this created awareness about reading (Lewandowicz-Nosal, 2017). Following the successful results of the campaign, this practice was first launched in the Czech Republic and later all across Europe (All of Europe Reads to Kids) (OECD, 2012). The first task in breaking the "illiterate literate" phenomenon in Turkey rests within the family, the first link of the chain. It is thought that the reading culture that will be formed in the first grade of school and the attitudes and behaviors of the teacher are important in creating reading habits for the teacher's students. The current situation reveals that systematic studies and campaigns covering the dimensions of family and school are needed to instill reading habits for future generations in Turkey.

The findings of the research indicate that there is a significant relationship between pre-service teachers' reading habits, attitudes, the number of children's books they read during university education, and whether or not they took a children's literature course and their competence in selecting illustrated children's books. Turan et al. (2017) found that the competence scores of third grade pre-service teachers were higher than those of second and fourth grade teachers. In their studies comparing the opinions of the third and fourth grade pre-service preschool teachers on children's books, Ergün and Gündüz (2011) did not find any difference according to grade level; the study was carried out with all pre-service teachers at all grade levels. Pre-service teachers were compared according to whether they had taken a children's literature course, and there was a meaningful result in favor of those who had taken the course. In the current study, the result that pre-service teachers who had taken a course on children's literature had higher competency scores in selecting illustrated children's books was an expected result. In the scope of such a course, pre-service teachers acquire theoretical knowledge about the properties that the illustrated children's books should have and gain experience through applying the knowledge learning in the course. The main focus of the current study was to investigate the relationship between pre-service teachers' personal reading habits, attitudes, and experiences, as well as taking a children's literature course and their competence in selecting illustrated children's books. The findings revealed that pre-service teachers who had better reading attitudes and habits and who had to read more children's books during university education had higher 
scores for their competence in selecting illustrated children's books. Pre-service teachers gain experience about the style and expression methods used in stories, topics, illustrating techniques (watercolor, pastel, oil painting, digital, etc.) and book design through the children's books they read. It is believed that this experience supports their competence in selecting illustrated children's books. Therefore, it can be said that it is important for preservice teachers to follow and read the picture stories published in children's literature when choosing books that are appropriate for the developmental levels of the children.

There is a strong relationship between the reading habits and attitudes of pre-service teachers. However, studies have also shown that there is a relationship between reading habits and attitudes and critical thinking skills (Gündüz, 2015; Karasakaloğlu, Saraçoğlu, \& Yılmaz-Özelçi, 2012; Koçak, Kurtlu, Ulaş, \& Epçaçan, 2015). Karasakaloğlu et al. (2012) found that the critical thinking and metacognitive competence scores of pre-service Turkish teachers differed according to their reading habits. Their study showed that pre-service teachers reading 21 or more books a year had higher critical thinking and metacognitive competence scores than those who read from 1-5 and 6-20 books per year. Gündüz (2015) found that there was a strong $(r=.60)$ relationship between the reading habits of freshmen and their ability to think critically. According to the results of Güven and Aktaş's (2014) study, which was carried out with 627 fifth graders, students with longer daily reading times also had high scores in visual reading and critical thinking skills. They found a significant positive relationship between visual reading ability and critical thinking ability $(r=.31)$. From these results, the reading habits of pre-service teachers may contribute to their competence in selecting illustrated children's books both directly by increasing their experience of children's books and indirectly by supporting their cognitive development, such as critical thinking and metacognition. The relationships among these variables could be identified more clearly in future studies using the structural equation modeling of the relevant variables. In this context, the current study is important in terms of considering the variables that may be related to the competence of pre-service teachers in selecting illustrated children's books. There is also a need for research to determine the competence of pre-service teachers and employed teachers in selecting illustrated children's books and the factors that influence this competence. 
Altun, D. (2018). Pre-Service Preschool Teachers' Reading Habits, Attitudes, and Experiences as Predictors of Their Level of Competence in Selecting Children's Illustrated Storybooks. Bartin University Journal of Faculty of Education, 7(3), 826-852

\title{
Okul Öncesi Öğretmen Adaylarının Okuma Alışkanlıkları, Tutumları ve Deneyimlerinin Resimli Hikâye Kitabı Seçme Yeterliliklerini Yordama Düzeyi
}

\begin{abstract}
Giriș
Hikâye dinleme ve okuma, çocukların hem ev-içi hem de okul öncesi eğitim kurumlarında gelişimlerinin eğlenerek desteklendiği önemli etkinliklerden biridir. Yapılan araştırmalar okunan ve anlatılan hikâyelerin çocukların anlama, anlatma, kelime hazinesi, yazı farkındalığı, prososyal davranışlar ve matematik becerileri gibi birçok alanda gelişimlerine katkı sağladığını göstermektedir (Altun, 2016; Bus, van Ijzendoorn, \& Pellegrini, 1995; Flack, Field, \& Horst, 2017; HepBurn, Egan, \& Flynn, 2010; Uzmen \& Mağden, 2002). Resimli çocuk kitapları okul öncesi dönemde birçok kazanım, konu ve kavramın çocuklara kazandırılmasında bağlam oluşturmaktadır (Ulusoy \& Altun, 2017). Ayrıca, erken çocukluk döneminde çocuklara sağlanan düzenli ve ilgi çekici kitap okuma etkinlikleri onların okumaya karşı olumlu tutum geliştirmelerine de katkı sağlamaktadır (Altun, 2013). Uluslararası literatürde evde ve okul öncesi sınıflarında bulunan kitap sayısı okuryazarlık ortamının ve okuma kültürünün önemli bir göstergesi olarak kabul edilmektedir (Evans, Kelley, \& Sikora, 2014; Evans, Kelley, Sikora, \& Treiman, 2010; Smith, Brady, \& Anastasopoulos, 2008). Bu nedenle, çocuklara sunulacak zengin içerikte, kaliteli çocuk kitapları çocukların gelişimlerini desteklemek adına büyük önem taşımaktadır.
\end{abstract}

\section{Resimli Çocuk Kitapları}

Resimli çocuk kitabı çocukların gelişim düzeylerine uygun, onların ilgilerini çekecek farklı içerik ve formatta hazırlanmış kitapları tanımlayan geniş kapsamlı "șemsiye" bir terimdir (Kiefer, Hepler \& Hickman, 2007). Oyuncak kitaplar, ABC kitapları, kavram kitapları, etkinlik kitapları, sayı kitapları, yazısız kitaplar, tahmin kitapları ve resimli hikâye kitapları resimli çocuk kitaplarının başlıca çeşitleridir (Kiefer vd., 2007; Ural, 2015). Resimli hikâye kitapları, yazılı hikâye metninin görseller ile desteklenerek hem çocukların görsel okuma yoluyla hikâyeyi takip etmelerini kolaylaştırmakta hem de onların ilgilerini çekmek suretiyle eğlenerek öğrenmelerini sağlamaktadır. Resimli hikâye kitapları sadece yazılı metin aracılığıyla değil aynı zamanda görseller aracılığıyla da çocukların anlam kurma ve aktif öğrenmelerine olanak sağlamaktadır. Painter, Martin ve Unsworth (2013) resimli çocuk kitaplarında yer alan görsellerin anlam kurma sürecindeki rolüne odaklanarak,-çocuk kitaplarında yer alan görsellerin (metin içi ve metin çevresi: ön ve arka kapak, ilk sayfa) semiyotik/göstergebilim bağlamında çocuklar tarafından nasıl anlamlandırıldığını ele almışlardır. Çocukların hikâyeler ile ilgili görsel anlatımlarını inceleyen çalışmalar çocukların hem okuma sırasında metni anlama sürecinde hem de okuma sonrası metni anlatma sürecinde görsellerden yararlandıklarını göstermektedir (Arizpe \& Styles, 2004; Ulusoy \& Altun, 2016; 2017).

Guijarro (2014) çocukların resimli hikâye kitapları ile olan etkileşimlerini artırmak için seviyelerine uygun kitap seçilmesi gerektiğini belirtmektedir. Resimli hikâye kitapları çocukların gelişim seviyelerine uygun konu ve anlatıma sahip olmalıdır. Ayrıca, kitaplar fiziksel özellikleri, tasarım ve resimleme özellikleri açılarından da çocukların gelişim seviyelerine uygun olarak hazırlanmalıdır. Guijarro (2014) okul öncesi dönem çocuklarına yönelik çocuk kitaplarını Piaget'in Bilişsel Gelişim Aşamalarına göre iki başlık altında ele almıştır. Bunlar; duyusal- motor dönem çocukları için hazırlanması gereken kitaplar ve işlem öncesi dönem çocukları için hazırlanması gereken kitaplardır. Kiefer vd. (2007) ise çocukların yaş ve gelişim düzeylerine göre kitapları altı başlık altında ele almışlardır. Bu basamaklar: a) Bebeklik Dönemi (0-3 yaş), b) Okul Öncesi (3-5 yaş), c) İlkokulun İlk Kademesi (6-7 yaş), d) İlköğretimin Orta Kademesi (8-9 yaş), e) İlköğretimin Son Kademesi (10-11 yaş) ve f) Ortaokul (12-14 yaş). Kiefer vd.'nin (2007) sınıflamasına göre erken çocukluk dönemi kitapları 0-3 yaş ve 3-5 yaş olmak üzere iki döneme ayrılmaktadır. Gönen, Uludağ, Fındık-Tanrıbuyurdu ve Tüfekçi (2014) okul öncesi dönem çocuk kitaplarının 0-3 yaş ve 3-6 yaş olarak iki grup altında incelenebileceğini belirtmişlerdir. Benzer şekilde Yükselen (2017) çocuk kitaplarını 0-3 yaş, 4-6 yaş ve 7-9 yaş olmak üzere üç başlıkta ele almıştır. Okul öncesi 0-3 yaş çocuklar için hazırlanacak kitapların çocukların dikkat süresi kısa olduğu için az sayfalı, bol resimli ve kısa metinli yazılması önerilmektedir (Kiefer vd., 2007). Kitaplarda çocukların çevrelerinde gördüğü nesneler, eylemler (beslenme, giyinme vb.), canlılar ve aile bireylerine yer verilebileceği belirtilmektedir. Ayrıca çocukların aile bireyleri ve diğer insanlarla ilişkilerinde güven inşa edecek şefkat, sevgi ve arkadaşlık gibi konuların önemli olduğu ifade edilmektedir. Kitaplarda yer verilecek kısa diyalogların ve kafiyeli söz oyunlarının hem çocukların dikkatlerini çekme hem de çocukların dil gelişimini desteklemek için tercih edilmelidir Çocukların kitapları manipüle edebilmeleri için kolayca kaldırıp tutabilecekleri hafiflikte, sayfaları çevirebilecekleri kalınlıkta ve 
dokunma duyularına hitap edecek özellikte olmaları önerilmektedir (Gönen vd., 2014; Gönen, Burçak, Uysal, \& Bediz, 2017; Kiefer vd., 2007; Yükselen, 2017).

Artan yaş ile birlikte çocukların dil, psikomotor, sosyo-duygusal ve bilişsel alanlarında gözlenen gelişimlere bağlı olarak 3-6 yaş grubuna yönelik hazırlanacak kitapların 0-3 yaş grubu kitaplarından farklı özellikler taşıması gerekmektedir (Guijarro, 2014; Kiefer vd., 2007). Kitaplarda içerik açısından çocukların artan hayal güçlerini destekleyecek, yeni konu ve kavramları öğrenmesine olanak sağlayacak konulara yer verilmelidir. Ayrıca, çocukların hikâyeler aracılığıyla duygularını yansıtabilecekleri (mutlu, üzgün, karanlık- anneden yarılma korkusu, yeni kardeş vb.) farklı konulara yer verilmesi önerilmektedir (Kiefer vd., 2007; Yükselen, 2017). Çocukların artan bilişsel beceriler ile olay örgüsünü sıralayabileceği önce-şimdi- sonra gibi zaman kavramlarına da kitaplarda yer verilebilir (Yükselen, 2015). Çocuklarda bu dönemde egosentrik düşünce hâkim olduğu için kendileri ile özdeşim kurabilecekleri hikâye karakterlerine yer verilmesi önemlidir. Kiefer vd. (2007) çocukların hafizalarında yer edinecek etkileyici ve güçlü hikâye karakterlerinin oluşturulmasının önemli olduğunu belirtmektedirler. Ayrıca, hikâyenin içeriği ve karakterleri aracılığılla çocuklarda ırk ve toplumsal cinsiyet rolleri gibi çeşitli stereotipler oluşturmalarına neden olacak kitaplardan kaçınılması gerektiği vurgulanmaktadır (Çatalcalı Soyer, 2009; Kiefer vd., 2007).

Çocukların gelişim düzeylerine uygun kitapların taşıması gereken özellikler ilgili alanyazında vurgulanmasına rağmen yapılan çalışmalar yayınlanan çocuk kitaplarının içerik ve format özellikleri açısından sıkıntılar taşıdığını göstermektedir (Çatalcal1-Soyer, 2009; Dağlıoğlu \& Çamlıbel-Çakmak, 2009; Veziroğlu \& Gönen, 2012). Dağlıŏglu ve Çamlıbel-Çakmak (2009) okul öncesi dönem 174 hikâye kitabını şiddet ve korku ögeleri açısından incelemişlerdir. Çalışma sonuçlarına göre kitaplarda $\% 8$ şiddet ve $\% 11$ korku ögesine yer verildiğini tespit etmişlerdir. Çatalcalı Soyer (2009) 50 adet çocuk kitabını inceleyerek hikâyelerde yer verilen stereotipleri toplumsal cinsiyet, aile (modern-geleneksel) ve toplum yapısı (kent-kır) ortaya koymuştur. Veziroğlu ve Gönen (2012) 250 adet resimli çocuk kitabını 2006 Okul Öncesi Eğitim Programı'nda yer verilen kazanımlara uygunluğu açısından ele almışladır. Çalışma kapsamında incelenen resimli çocuk kitapları 2006 programında yer verilen 264 kazanımın sadece \%18.5'ini karşılamaktadır. Bu nedenle, okul öncesi öğretmenlerinin piyasada yayınlanan kitaplar arasından çocukların gelişim düzeylerine uygun kitapları seçmeleri önem taşımaktadır. Çocuk edebiyatı dersi kapsamında öğretmen adaylarına teorik olarak çocuk kitapları hakkında bilgiler verilmekte ve çocukların gelişim seviyelerine uygun örnek kitaplar paylaşılmaktadır. Çocuk edebiyatı dersi kapsamında aldıkları eğitimin yanında, öğretmen adaylarının kişisel okuma alışkanlıkları, deneyimleri ve tutumlarının okuma kültürü oluşturmada ve uygun kitap seçmede etkili olabileceği düşünülmektedir.

\section{Öğretmen Adaylarının Okumaya İlişskin Tutumları ve Okuma Alışkanlıkları}

Yapılan çalışmalar, öğretmen adaylarının düşük okuma alışkanlığına (Gür, 2014; Odabaş, Odabaş \& Polat, 2008; Sağlam, Suna \& Çengelci, 2007; Saraçoğlu, Karasakaloğlu \& Aslantürk, 2010) ve okuma tutumuna (Dedeoğlu \& Ulusoy, 2013; Saraçoğlu vd., 2010) sahip olduğunu göstermektedir. Öğretmen, öğretmen adayı, aile ve öğrenci gibi çeşitli katılımcı grupları ile yapılan çok sayıda çalışma (Bayram, 2001; Karaşahin, 2009; Konan, 2013; Kuş \& Türkyılmaz, 2010; Mavi \& Çetin, 2009; Şengül Bircan, 2017; Yılmaz, 2002) ülkemizde okumayan okuryazarlar (illiterate literates) (Huck, 1973) olgusunun yaygın olduğunu göstermektedir.

McKenna'nın (1994) okuma tutum modeline göre, bireylerin okumaya karşı tutumları kültürel bağlamdan ve sosyal çevreden etkilenmektedir. (Mckenna, Kear \& Elisworth, 1995). Okul öncesi dönemde çocukların ev-içi okuryazarlık ortamları ile okuma tutumları arasında ilişki bulunmaktadır (Altun, 2013). Yapılan çalışmalar bireyin okumaya karşı tutumu ile okuma alışkanlığı ve okuduğunu anlama düzeyleri arasında ilişki bulunduğunu göstermektedir (Baccus, 2004; Kırmızı, 2011; Petscher, 2010; PIRLS, 2011; Sallabaş, 2008; Sonleitner, 2005). Birey okumaya ilişkin deneyimlerine bağlı olarak okumaya karşs bir tutum oluşturmakta ve oluşturduğu tutuma göre de okuma yaşantılarını düzenlemektedir. Öğretmen adaylarının okuma tutumları ve alışkanlıklarına bağlı olarak kitaplar hakkında kazandıkları deneyimlerin resimli çocuk kitapları seçme yeterlilikleri üzerine etkisi olabileceği düşünülmektedir. Bu çalışma kapsamında öğretmen adaylarının kişisel okuma kültür ve deneyimlerinin resimli çocuk kitabı seçme yeterlilikleri olan ilişkisinin incelemesi hedeflenmiştir. Bu hedefle çalışmada aşağıdaki sorulara cevap aranmıştır. 
1) Okul öncesi öğretmen adaylarının çocuk edebiyatı dersini alıp almama durumlarına göre resimli hikâye kitabı seçme yeterlilik düzeyleri arasında anlamlı fark var mıdır?

2) Okul öncesi öğretmen adaylarının çocukluklarında ailelerinin kendilerine kitap okuma sıklığına göre resimli hikâye kitabı seçme yeterlilik düzeyleri arasında anlamlı fark var mıdır?

3) Okul öncesi öğretmen adaylarının çocukluklarında ailelerinin kendilerine kitap okuma sıklığına göre okuma tutum puanları arasında anlamlı fark var midır?

4) Okul Öncesi öğretmen adaylarının kişisel okuma alışkanlık, tutum ve deneyimleri resimli hikâye kitabı seçme yeterliliklerini ne ölçüde yordamaktadır?

\section{Yöntem}

\section{Araştırma Modeli}

Okul öncesi öğretmen adaylarının resimli hikâye kitabı seçme yeterlilikleri ile kişisel okuma alışkanlığı, tutum ve deneyimleri arasındaki ilişkiyi araştıran bu çalışmada ilişkisel tarama modeli kullanılmıştır.

\section{Çalışma Grubu}

Araştırmanın katılımcıları 2017-2018 eğitim-öğretim yılı güz döneminde bir devlet üniversitesinin Okul Öncesi Eğitimi Anabilim Dalında öğrenim gören 213 (Kadın: 172, Erkek: 41) öğretmen adayıdır. Çalışmanın katılımcıları uygun örnekleme yöntemi ile seçilmiştir. Çalışmaya katılan öğretmen adaylarına ilişkin detaylı bilgi Tablo 1.'de sunulmuştur.

Tablo 1. Öğretmen Adaylarına İlişkin Demografik Bilgiler

\begin{tabular}{lcc}
\hline Cinsiyet & $\boldsymbol{f}$ & $\boldsymbol{\%}$ \\
Kız & 172 & 80.8 \\
Erkek & 41 & 19.2 \\
Toplam & 213 & 100 \\
\hline Sınıf & & \\
1 & 59 & 27.7 \\
2 & 46 & 21.6 \\
3 & 57 & 26.8 \\
4 & 51 & 23.9 \\
Toplam & 213 & 100 \\
\hline Çocuk Edebiyatı Dersi & & \\
Alan & 122 & 57.3 \\
Almayan & 91 & 42.7 \\
Toplam & 213 & 100 \\
\hline Çocukluklarında ailelerinin kendilerine kitap & & \\
okuma siklığ & & \\
Hiçbir zaman & 111 & 52.1 \\
Ayda bir & 41 & 19.2 \\
Haftada bir & 39 & 18.3 \\
Her gün & 22 & 10.3 \\
Toplam & 213 & 100 \\
\hline
\end{tabular}

Araştırma grubunu oluşturan öğretmen adaylarının \%27.7'si birinci sınıf, \%21.6'sı ikinci sınıf, \%26.8'i üçüncü sınıf ve \%23.9'u dördüncü sınıf öğrencileridir. Öğretmen adaylarının \%57.3'ü çocuk edebiyatı dersini almışlardır. Çocuk edebiyatı dersi 2. sınıf bahar döneminde verilen zorunlu bir derstir. Öğretmen adaylarında 17'si ikinci üniversitesini okumakta ya da dikey geçiş öğrencisidir. İntibakları 1. veya 2. sınıfa yapılan bu öğrenciler çocuk edebiyatı dersini geldikleri üniversitede daha önceden almışlardır. Bu nedenle çocuk edebiyatı dersini alan öğrenci oranında artış meydana gelmiştir. 
Öğretmen adaylarının cevaplarına göre çocukluklarında \%52.1'nin aileleri kendilerine hiç kitap okumamıştır. Öğretmen adaylarının \%10.3'ü ise ailelerinin kendilerine günlük düzenli olarak kitap okuduğunu belirtmişlerdir.

\section{Veri Toplama Araçları}

Çalışmanın verileri Okul Öncesi Öğretmen Adaylarının Resimli Öykü Kitaplarını Seçme Konusunda Yeterlik Düzeyleri ve Kendi Yeterliklerine İlişkin Algılarını Belirleme Formu (Turan, Gönen, \& Aydos, 2017), Mikulecky Davranışsal Okuma Tutum Ölçeği (Dedeoğlu \& Ulusoy, 2013) ve demografik bilgi formu kullanılarak toplanmıştır.

Okul Öncesi Öğretmen Adaylarının Resimli Öykü Kitaplarını Seçme Konusunda Yeterlik Düzeyleri ve Kendi Yeterliklerine İlişkin Algılarını Belirleme Formu

Form öğretmen adaylarının resimli hikâye kitabı seçme konusunda öz yeterliliklerini ölçmek amacıyla hazırlanmıştır. Form içerik, resimleme ve fiziksel özellikler olmak üzere üç bölümden oluşmaktadır (Turan vd., 2017), Formda 5'li likert tipinde (yetersiz - çok iyi) toplam 59 madde bulunmaktadır. Fiziksel özellikler başlı̆̆ altında 10 madde, içerik başlığı altında 28 madde ve resimleme başlığı altında 21 madde bulunmaktadır (Turan vd., 2017). Bu çalışma kapsamında form 213 öğretmen adayına uygulandıktan sonra formun her bir alt boyutu için Cronbach alfa değerleri hesaplanmıştır. Fiziksel özellikler alt boyutu için Cronbach alfa değeri.84, içerik alt boyutunun Cronbach alfa değeri.91 ve resimleme alt boyutunun Cronbach alfa değeri ise. 82 bulunmuştur.

\section{Mikulecky Davranışsal Okuma Tutum Ölçeği}

Mikulecky (1976) tarafından yetişkinlerin okumaya ilişkin tutumlarını ölçmek amacıyla hazırlanmıştır. Ölçek 5'li likert tipinde (Hiç bana göre değil - tam bana göre) 20 maddeden oluşmaktadır. Ölçekteki maddeler Krathwohl'un Duyuşsal Alan Taksonomisinin beş basamağına uygun olarak hazırlanmıştır. Bu basamaklar: a) okumanın farkında olma, b) okumaya ilişkin olumlu yaklaşım, c)okumayı önemli bir değer olarak görme, d) organize etkinlik olarak okuma ve e) kişiliğin parçası olarak okumadır (Dedeoğlu \& Ulusoy, 2013, s.82; Richardson, Morgan, \& Fleener, 2009, s.477). Türkçeye uyarlama çalışması Dedeoğlu ve Ulusoy (2013) tarafindan yapılmıştır. Warmack (2007) öğretmen adayları ile yürüttüğü çalışmasında ölçeğin Cronbach alfa değerini. 92 olarak hesaplamıştır. Ölçeğin Türkçeye uyarlanması aşamasında 120 sınıf öğretmeni adayı ile yapılan pilot çalışmada ise Cronbach alfa değeri.86 olarak bulunmuştur (Dedeoğlu \& Ulusoy, 2013). Bu çalışma kapsamında ölçeğin Cronbach alfa değeri.88 olarak bulunmuştur.

\section{Demografik Bilgi Formu}

Form aracılığıyla öğretmen adayları hakkında çeşitli demografik bilgiler toplanmıştır. Bu bilgiler cinsiyet, sınıf, çocuk edebiyatı dersi alıp almama durumları, çocukluklarında ailelerinin kendilerine kitap okuma sıklıkları, haftalık okuma süreleri, son bir yılda okudukları kitap sayısıdır.

\section{Verilerin Toplanması}

Öğretmen adaylarına 2017-2018 eğitim öğretim yılı güz döneminde ilgili veri toplama araçları sınıf ortamında dağıtılıp öğretmen adaylarından soruları dikkatlice okuyarak hiçbir soruyu boş bırakmadan doldurmaları istenmiştir. Veri toplama araçlarının uygulanma süresi ortalama 35 dakika sürmüştür.

\section{Verilerin Analizi}

Çalışma kapsamında elde edilen veriler IBM SPSS 22.00 paket programına aktarılarak betimsel ve çıkarımsal istatistik yöntemleri (bağımsız örneklem t-testi, tek yönlü ANOVA, Pearson korelasyon, çoklu regresyon) kullanılarak analiz edilmiştir. 


\section{Bulgular}

Öğretmen adaylarının, çalışma kapsamında uygulanan veri toplama araçlarından aldıkları puanlar ve bu puanların dağılımına ilişkin detaylı bilgi Tablo 2.'de sunulmuştur. Veri setlerine ilişkin Skewness ve Kurtosis değerleri incelediğinde, değerlerin $(-2,+2)$ aralığında olduğu için normal dağılımı sağladığını göstermektedir (Tabachnick \& Fidell, 2007). Ayrıca, histogram grafikleri de puanların normal dağılım gösterdiğini desteklemektedir.

Tablo 2. Öğretmen Adaylarının Veri Toplama Araçlarından Aldıkları Puanlar ve Dağılımı

\begin{tabular}{|c|c|c|c|c|c|c|c|}
\hline Değişkenler & $n$ & Min & $\operatorname{Max}$ & $M$ & $S D$ & Skewness & Kurtosis \\
\hline \multicolumn{8}{|l|}{$\begin{array}{l}\text { Resimli Çocuk Kitapları } \\
\text { Seçme Yeterlilikleri }\end{array}$} \\
\hline Fiziksel Özellikler & 213 & 30 & 50 & 45.03 & 4.26 & -.73 & .180 \\
\hline İçerik Özellikleri & 213 & 78 & 140 & 123.78 & 9.90 & -1.12 & 1.26 \\
\hline Resimleme Özellikleri & 213 & 75 & 105 & 97.66 & 7.74 & -1.05 & .20 \\
\hline Okuma Tutum & 213 & 33 & 100 & 77.84 & 12.47 & -.612 & .25 \\
\hline $\begin{array}{l}\text { Haftalık Kitap Okuma Süre } \\
\text { (dakika) }\end{array}$ & 213 & 0 & 250 & 117.10 & 17.85 & 1.145 & .40 \\
\hline $\begin{array}{l}\text { Üniversite eğitimi boyunca } \\
\text { okunan çocuk kitap sayısı }\end{array}$ & 213 & 0 & 25 & 8.51 & 3.92 & 1.60 & 1.72 \\
\hline $\begin{array}{l}\text { Son bir y1lda okunan kitap } \\
\text { say1s1 }\end{array}$ & 213 & 0 & 20 & 6.21 & 2.90 & 1.74 & 1.87 \\
\hline
\end{tabular}

Öğretmen adaylarının haftalık kitap okuma süreleri 0 ile 250 dakika arasında değişmektedir. Öğretmen adaylarından 19 tanesi hiç kitap okumadıklarını belirtmişlerdir. Öğretmen adaylarının haftalık kitap okuma süreleri ortalaması $117.10(S D=17.85)$ dakikadır. Öğretmen adaylarının üniversite eğitimleri boyunca okudukları ortalama çocuk kitap sayısı 8.51'dir $(S D=3.92)$. Son bir yılda öğretmen adaylarının okudukları ortalama kitap sayıs1 6.21'dir $(S D=2.90)$.

Ö̆̆retmen adaylarının çocuk edebiyatı dersini alıp almama durumuna göre resimli hikâye kitabı seçme yeterlilik düzeyleri

Öğretmen adaylarının resimli çocuk kitapları seçme konusunda yeterlilikleri formundan aldıkları puanların çocuk edebiyatı dersi alıp almama değişkenine göre anlamlı bir farklılaşma gösterip göstermediğini incelemek amacıyla bağımsız örneklem t-testi uygulanmıştır. Levene varyans testi sonuçlarına göre çocuk edebiyatı alan ve almayan gruplar arası fiziksel özellikler, içerik ve resimleme puanlarına ilişkin varyanslar ( $\mathrm{p}>.05$ ) homojendir (Pallant, 2010).

Öğretmen adaylarının resimli hikâye kitaplarını fiziksel özellikler açısından seçme yeterlilik puanları arasında çocuk edebiyatı dersi alanlar lehine anlamlı bir fark bulunmuştur $(\mathrm{t}(211)=3.441, \mathrm{p}<.05)$. Çocuk edebiyatı dersini alan $(\mathrm{M}=45.88, \mathrm{SD}=4.12)$ ve almayan grupların $(\mathrm{M}=43.10, \mathrm{SD}=4.34)$ puanları arasında bulunan anlamlı farkın etki değeri ( $\eta 2)$ hesaplanmıştır. Hesaplanan eta kare değeri incelendiğinde $(\eta 2=.05)$ gruplar arasında bulunan farka ilişkin etki değerinin küçük olduğu görülmektedir. 
Tablo 3. Çocuk Edebiyatı Dersini Alıp Almama Durumuna Göre Öğretmen Adaylarının Resimli Hikâye Kitabı Seçme Yeterlilik Puanlarının Bağımsız Örneklem t-Testi Sonuçları

\begin{tabular}{llcccccc}
\hline \multicolumn{2}{l}{} & $\mathbf{n}$ & M & SD & t & p & $\boldsymbol{\eta 2}$ \\
\hline $\begin{array}{l}\text { Resimli Çocuk Kitapları Seçme } \\
\text { Yeterlilik }\end{array}$ & & & & & & \\
\hline Fiziksel Özellikler & Alan & 122 & 45.88 & 4.12 & 3.441 & .001 & .053 \\
& Almayan & 91 & 43.10 & 4.34 & & & \\
\hline İçerik Özellikleri & Alan & 122 & 126.10 & 9.56 & 3.010 & .003 & .041 \\
& Almayan & 91 & 120.69 & 10.24 & & & .061 \\
\hline Resimleme & Alan & 122 & 99.40 & 9.90 & 3.715 & .000 & .061 \\
Özellikleri & Almayan & 91 & 95.45 & 8.85 & & & \\
\hline
\end{tabular}

Öğretmen adaylarının resimli hikâye kitaplarını içerik açısından seçme yeterlilik puanları arasında çocuk edebiyatı dersi alanlar lehine anlamlı bir fark bulunmuştur $(\mathrm{t}(211)=3.010, \mathrm{p}<.05)$. Çocuk edebiyatı dersini alan $(\mathrm{M}=126.10, \mathrm{SD}=9.56)$ ve almayan $(\mathrm{M}=120.69, \mathrm{SD}=10.24)$ grupların puanları arasında bulunan anlamlı farkın etki değeri $(\eta 2)$ hesaplanmıştır. Hesaplanan eta kare değeri incelendiğinde $(\eta 2=.04)$ bulunan farka ilişkin etki değerinin küçük olduğu görülmektedir.

Çocuk edebiyatı dersi alan ve almayan grupların resimleme özellikleri formundan aldıkları puanlar arasında anlamlı bir fark bulunmaktadır $(\mathrm{t}(211)=3.715, \mathrm{p}<.05)$. Çocuk edebiyatı dersini alanların lehine bulunan anlamlı farkın etki değeri $(\eta 2)$ hesaplanmıştır. Hesaplanan eta kare değeri incelendiğinde $(\eta 2=.06)$ gruplar arasında bulunan farkın orta etki değerinde olduğu görülmektedir. Detaylı bilgi Tablo 3 'de sunulmuştur.

\section{Okul Öncesi Öğretmen Adaylarının Çocukluklarında Ailelerinin Kendilerine Kitap Okuma Sıklıklarına Göre Resimli Hikâye Kitabı Seçme Yeterlilik Düzeyleri}

Öğretmen adaylarının resimli çocuk kitapları seçme yeterlilikleri formundan aldıkları puanların çocukluklarında ailelerinin kendilerine kitap okuma sıklıkları değişkenine göre anlamlı bir farklılaşma gösterip göstermediğini incelemek amacıyla tek yönlü varyans analizi uygulanmıştır. Levene varyans testi sonuçları resimli hikâye kitapları seçme yeterlilikleri alt formları için incelenmiş ve gruplar arasında varyanslar ( $\mathrm{p}>.05)$ homojen bulunmuştur (Pallant, 2010).

Tek yönlü varyans analizi sonuçlarına göre okul öncesi öğretmen adaylarının resimli çocuk kitaplarını fiziksel özellikler açısından seçme yeterlilikleri formundan aldıkları puanlarında, çocukluk döneminde ailelerinin kendilerine kitap okuma sıklıklarına göre anlamlı bir farklılaşma bulunmamaktadır $(F[3,209]=2.112, p>.05, \eta 2$ $=.03)$.

Tablo 4. Öğretmen Adaylarının Çocukluklarında Ailelerinin Kendilerine Kitap Okuma Sıklıklarına Göre Resimli Çocuk Kitaplarını Fiziksel Özellikleri Açısından Seçme Yeterlilik Düzeyleri

\begin{tabular}{lcccccc}
\hline $\begin{array}{l}\text { Fiziksel } \\
\text { Özellikler }\end{array}$ & $\begin{array}{c}\text { Kareler } \\
\text { Toplamı }\end{array}$ & $\boldsymbol{s d}$ & $\begin{array}{c}\text { Kareler } \\
\text { Ortalaması }\end{array}$ & $\boldsymbol{F}$ & $\boldsymbol{p}$ & $\boldsymbol{\eta}^{2}$ \\
\hline Gruplar aras1 & 113.610 & 3 & 37.870 & .251 & .10 & .029 \\
Grup içi & 3748.089 & 209 & 17.933 & & & \\
Toplam & 3861.700 & 212 & & & & \\
\hline
\end{tabular}

Tablo 5'de görüldüğü gibi okul öncesi öğretmen adaylarının resimli çocuk kitaplarını içerik özellikleri açısından seçme yeterlilikleri formundan aldıkları puanlarında, ailelerinin çocuklukta kendilerine kitap okuma sıklıkları göre anlamlı bir farklılaşma bulunmaktadır $(\mathrm{F}[3,209]=7.283, \mathrm{p}<.05, \eta 2=.09)$.

Gruplar arasında tespit edilen anlamlı farkın araştırılması amacıyla Scheffe testi uygulanmıştır. Scheffe testi sonucuna göre çocukluklarında ailelerinin kendilerine hiç kitap okumadığını belirten grup ( $\mathrm{M}=121.02$, 
$\mathrm{SD}=10.04)$ ile hafta bir gün $(\mathrm{M}=128.25, \mathrm{SD}=9.17)$ ve her gün $(\mathrm{M}=132.77, \mathrm{SD}=8.91)$ kendilerine kitap okunduğunu belirten gruplar arasında anlamlı fark bulunmaktadır.

Tablo 5. Öğretmen Adaylarının Çocukluklarında Ailelerinin Kendilerine Kitap Okuma Sıklıklarına Göre Resimli Çocuk Kitaplarını İçerik Özellikleri Puanlarına İlişkin Tek Yönlü Varyans Analizi Sonuçları

\begin{tabular}{llllllc}
\hline $\begin{array}{l}\text { İcerik } \\
\text { Özellikleri }\end{array}$ & $\begin{array}{l}\text { Kareler } \\
\text { Toplamı }\end{array}$ & $\boldsymbol{s d}$ & $\begin{array}{l}\text { Kareler } \\
\text { Ortalamast }\end{array}$ & $\boldsymbol{F}$ & $\boldsymbol{p}$ & $\boldsymbol{\eta} \mathbf{2}$ \\
\hline Gruplar aras1 & 3504.835 & 3 & 1168.278 & 7.283 & .000 & .09 \\
Grup içi & 33524.657 & 209 & 160.405 & & & \\
Toplam & 37029.493 & 212 & & & & \\
\hline
\end{tabular}

Tek yönlü varyans analizi testi sonuçlarına göre okul öncesi öğretmen adaylarının çocuk kitaplarında resimleme özellikleri açısından seçme yeterlilikleri formundan aldıkları puanlarında, çocukluk döneminde ailelerinin kendilerine kitap okuma sıklıklarına göre anlamlı bir farklılık bulunmaktadır $(\mathrm{F}[3,209]=4.68, \mathrm{p}<.05$, $\eta 2=.06)$. Gruplar arasında tespit edilen anlamlı farkın araştırılması amacıyla Scheffe testi yapılmıştır. Scheffe testi sonucuna göre çocukluklarında ailelerinin kendilerine hiç kitap okumadığını belirten grup $(\mathrm{M}=96.36, \mathrm{SD}=$ 8.11) ile kendilerine her gün $(\mathrm{M}=101.72, \mathrm{SD}=7.07)$ kitap okunduğunu belirten gruplar arasında anlamlı fark bulunmaktadır.

Tablo 6. Öğretmen Adaylarının Çocukluklarında Ailelerinin Kendilerine Kitap Okuma Sıklıklarına Göre Resimli Çocuk Kitaplarını Resimleme Özellikleri Puanlarına İlişkin Tek Yönlü Varyans Analizi Sonuçları

\begin{tabular}{lcccccc}
\hline $\begin{array}{l}\text { Resimleme } \\
\text { Özellikleri }\end{array}$ & $\begin{array}{l}\text { Kareler } \\
\text { Toplamı }\end{array}$ & $\boldsymbol{s d}$ & $\begin{array}{c}\text { Kareler } \\
\text { Ortalamast }\end{array}$ & $\boldsymbol{F}$ & $\boldsymbol{p}$ & $\boldsymbol{\eta}^{\mathbf{2}}$ \\
\hline Gruplar aras1 & 801.385 & 3 & 267.128 & 4.68 & .003 & .063 \\
Grup içi & 11909.948 & 209 & 56.985 & & & \\
Toplam & 12711.333 & 212 & & & & \\
\hline
\end{tabular}

Okul Öncesi Öğretmen Adaylarının Çocukluklarında Ailelerinin Kendilerine Kitap Okuma Sikliklarına Göre Okuma Tutumları

Öğretmen adaylarının okuma tutum puanlarında, ailelerinin kendilerine çocukluk döneminde kitap okuma sıklığına göre anlamlı bir farklılaşma gösterip göstermediğini incelemek amacıyla tek yönlü varyans analizi uygulanmıştır. Levene varyans testine göre öğretmen adaylarının okuma tutum puanlarında gruplar arasında varyanslar ( $\mathrm{p}>.05)$ homojendir (Pallant, 2010).

Tablo 7. Öğretmen Adaylarının Çocukluklarında Ailelerinin Kendilerine Kitap Okuma Sıklıklarına Göre Öğretmen Adaylarının Okuma Tutum Puanlarına İlişkin Tek Yönlü Varyans Analizi Sonuçları

\begin{tabular}{lcccccc}
\hline $\begin{array}{l}\text { Resimleme } \\
\text { Özellikleri }\end{array}$ & $\begin{array}{c}\text { Kareler } \\
\text { Toplamı }\end{array}$ & $\boldsymbol{s d}$ & $\begin{array}{c}\text { Kareler } \\
\text { Ortalamast }\end{array}$ & $\boldsymbol{F}$ & $\boldsymbol{p}$ & $\boldsymbol{\eta}^{2}$ \\
\hline Gruplar aras1 & 4700.595 & 3 & 1566.865 & 11.574 & .000 & .142 \\
$\begin{array}{l}\text { Grup içi } \\
\text { Toplam }\end{array}$ & 28293.977 & 209 & 135.378 & & & \\
\hline
\end{tabular}

Tek yönlü varyans analizi sonuçlarına göre okul öncesi öğretmen adaylarının okuma tutumları ölçeğinden aldıkları puanlarında, çocukluk döneminde ailelerinin kendilerine kitap okuma sıklıklarına göre anlamlı bir fark bulunmaktadır $(\mathrm{F}[3,209]=11.57, \mathrm{p}<.05, \eta 2=.14)$. Gruplar arasında tespit edilen anlamlı farkın araştırılması amacıyla Scheffe testi uygulanmıştır. Scheffe testi sonucuna göre ailelerinin kendilerine çocukluklarında hiç kitap okumadığını belirten grup $(\mathrm{M}=74.018, \mathrm{SD}=11.79)$ ile kendilerine hafta bir gün $(\mathrm{M}=83.74, \mathrm{SD}=12.07)$ ve her gün $(\mathrm{M}=86.68, \mathrm{SD}=11.19)$ kitap okunduğunu belirten gruplar arasında anlamlı fark bulunmaktadır.

Okul Öncesi Öğretmen Adaylarının Kişisel Okuma Allşkanlık, Tutum ve Deneyimleri Resimli Hikâye Kitabı Seçme Yeterliliklerini Arasindaki Ilişskinin İncelenmesi 
Okul öncesi öğretmen adaylarının resimli hikâye kitabı seçme yeterlilikleri ile kişisel okuma alışkanlık, tutum ve deneyimlerinin arasındaki ilişkiyi incelemek amacıyla Pearson Korelasyon analizi uygulanmıştır. İlgili analiz uygulanmadan önce veri setinde uç değer olup olmadığ 1 dağılım grafikleri (scatterplot) kontrol edilmiş ve uç değer bulunmadığı tespit edilmiştir. Pearson Korelasyon analiz sonuçlarına göre öğretmen adaylarının okuma tutum puanları ile resimli hikâye kitaplarının içerik açısından seçme yeterlilikleri arasında pozitif yönlü güçlü bir ilişki bulunmaktadır $(\mathrm{r}=.51, \mathrm{p}<.01)$. Öğretmen adaylarının okuma tutumları ile resimli hikâye kitapları seçme yeterlilik formunun resimleme $(\mathrm{r}=.45, \mathrm{p}<.01)$ ve fiziksel özellikler $(\mathrm{r}=.32, \mathrm{p}<.01)$ boyutlarıyla pozitif yönlü orta düzeyde bir ilişki bulunmaktadır. Öğretmen adaylarının haftalık kitap okuma süreleri ile resimli hikâye kitaplarının içerik açısından seçme yeterlilikleri arasında pozitif yönlü orta düzeyde bir ilişki bulunmaktadır $(\mathrm{r}=.33, \mathrm{p}<.01)$.

Tablo 8. Öğretmen Adaylarının Resimli Hikâye Kitabı Seçme Yeterlilikleri ile Kişisel Okuma Alışkanlık, Tutum ve Deneyimlerine İlişkin Pearson Korelasyon Analiz Sonuçları

\begin{tabular}{|c|c|c|c|c|c|c|c|}
\hline & 1 & 2 & 3 & 4 & 5 & 6 & 7 \\
\hline 1. Haftalık kitap okuma süresi & - & & & & & & \\
\hline 2. Son bir yılda okunan kitap sayıs1 & $.59 * *$ & - & & & & & \\
\hline $\begin{array}{l}\text { 3. Üniversite eğitimi boyunca } \\
\text { okunan çocuk kitap sayısı }\end{array}$ & $.26 * *$ & $.27 * *$ & - & & & & \\
\hline $\begin{array}{l}\text { 4. Resimli Hikâye Kitabı- İçerik } \\
\text { Özellikleri }\end{array}$ & $.33 * *$ & $.30 * *$ & $.25 * *$ & - & & & \\
\hline $\begin{array}{l}\text { 5. Resimli Hikâye } \quad \text { Kitabı- } \\
\text { Resimleme }\end{array}$ & .10 & $.18^{* *}$ & $.24 * *$ & $.63 * *$ & - & & \\
\hline $\begin{array}{l}\text { 6. Resimli Hikâye Kitabı- Fiziksel } \\
\text { Özellikler }\end{array}$ & $.19 * *$ & $.23 * *$ & $.23 * *$ & $.50 * *$ & $.54 * *$ & - & \\
\hline 7. Okuma Tutum & $.52 * *$ & $.48 * *$ & $.18 * *$ & $.51 * *$ & $.45 * *$ & $.32 * *$ & - \\
\hline
\end{tabular}

$* p<.05, * * \mathrm{p}<.01$

Öğretmen adaylarının üniversite eğitimleri boyunca okudukları çocuk kitabı sayısı ile resimli çocuk kitabı seçme yeterlilik boyutları; içerik $(\mathrm{r}=.25, \mathrm{p}<.01)$ fiziksel özellik $(\mathrm{r}=.23, \mathrm{p}<.01)$ ve resimle $(\mathrm{r}=.24, \mathrm{p}<.01)$ arasında pozitif yönlü düşük düzeyde bir ilişki bulunmaktadır. Tablo 8 'de detaylı bilgi sunulmuştur.

\section{Öğretmen Adaylarının Kişisel Okuma Alışkanlık, Tutum ve Deneyimlerinin Resimli Hikâye Kitabı Seçme Yeterliliklerini Yordama Düzeylerinin İncelenmesi}

Çoklu regresyon analizi uygulanmadan önce testin varsayımları üç model için de ayrı ayrı kontrol edilmiştir. Çoklu regresyon analizinin varsayımları olan örneklem büyüklüğü ( $\mathrm{N}>50+8 \mathrm{~m}, \mathrm{~m}=$ yordayıcısı sayısı), çoklu bağıntı (multicolinearity), eşvaryanslılık (homoscedasticity), uç değerler ve doğrusallık (linearity) veri setleri tarafından karşılanmaktadır. Öğretmen adaylarının çocuk edebiyatı dersini alıp almama durumları ikili (dichotomous/dummy) değişken olarak analize dâhil edilmiştir. 
Tablo 9. Resimli Hikâye Kitaplarının İçerik Özellikleri Puanlarının Yordanmasına İlişkin Çoklu Regresyon Analizi Sonuçları

\begin{tabular}{lcccccc}
\hline Yordayıclar & $\boldsymbol{B}$ & $\boldsymbol{\beta}$ & $\boldsymbol{t}$ & $\boldsymbol{p}$ & Tolerans & $\begin{array}{c}\text { Varyans arțS } \\
\text { değeri (VIF) }\end{array}$ \\
\hline Sabit & 81.293 & & 14.808 & .000 & & \\
$\begin{array}{l}\text { Üniversite eğitimi boyunca } \\
\text { okunan çocuk kitap sayısı }\end{array}$ & .392 & .204 & 3.020 & .003 & .687 & 1.456 \\
$\begin{array}{l}\text { Okuma Tutum } \\
\text { Haftalık kitap okuma }\end{array}$ & .415 & .391 & 5.852 & .000 & .700 & 1.429 \\
$\begin{array}{l}\text { süresi } \\
\text { Çocuk edebiyatı dersini }\end{array}$ & .006 & .057 & .836 & .404 & .674 & 1.483 \\
alıp almama & 4.478 & .168 & 2.600 & .010 & .748 & 1.337 \\
\hline
\end{tabular}

$R 2=.35$, Düzeltilmiş $R 2=.35, F(5,207)=27.82, p=.000$

Çoklu regresyon analiz sonuçlarına göre öğretmen adaylarının resimli hikâye kitaplarını içerik özellikleri açısından seçme yeterlilik puanları ile üniversitede okunan çocuk kitap sayısı, okuma tutum ve çocuk edebiyatı dersi alma değişkenleri arasında anlamlı bir ilişki bulunmaktadır $(\mathrm{F}=27.82, \mathrm{p}<.05)$. Modele göre ilgili yordayıcılar içerik özellikleri yeterlilik puanlarının toplam varyansının \%35'ini açıklamaktadır. Modele ilişkin standardize edilmiş beta $(\beta)$ katsayıları incelendiğinde okuma tutum $(\beta=.415, p<.05)$ değişkeninin diğer değişkenlere oranla güçlü bir yordayıcı olduğu görülmektedir. Haftalık kitap okuma süresi $(\beta=.006, p>.05)$ değişkeni modelin anlamlı bir yordayıcısı değildir. Tablo 9'da detaylı bilgi sunulmuştur.

Tablo 10. Resimli Hikâye Kitaplarının Resimleme Özellikleri Puanlarının Yordanmasına İlişkin Çoklu Regresyon Analiz Sonuçları

\begin{tabular}{|c|c|c|c|c|c|c|}
\hline Yordayıcılar & $B$ & $\beta$ & $t$ & $p$ & Tolerans & $\begin{array}{l}\text { Varyans artıs } \\
\text { değeri (VIF) }\end{array}$ \\
\hline Sabit & 71.560 & & 21.663 & .000 & & \\
\hline $\begin{array}{l}\text { Üniversite eğitimi } \\
\text { boyunca okunan çocuk } \\
\text { kitap sayıs1 }\end{array}$ & .212 & .188 & 2.716 & .007 & .687 & 1.456 \\
\hline Okuma Tutum & 277 & .447 & 6.500 & .000 & .700 & 1.429 \\
\hline $\begin{array}{l}\text { Haftalık kitap okuma } \\
\text { süresi }\end{array}$ & -.010 & -.152 & -2.177 & .031 & .674 & 1.483 \\
\hline $\begin{array}{l}\text { Çocuk edebiyatı dersini } \\
\text { alıp almama }\end{array}$ & 2.801 & .180 & 2.702 & .007 & .748 & 1.337 \\
\hline
\end{tabular}

$R 2=.31$, Düzeltilmiş $R 2=.31, F(5,207)=23.67, p<.05$

Hikâye kitaplarını resimleme özellikleri açısından seçme yeterlilik puanlarının yordayıcılarını incelemek amacıyla çoklu regresyon analizi yapılmışır. Analiz sonuçlarına göre üniversitede okunan çocuk kitap sayısı, okuma tutum, haftalık kitap okuma süresi ve çocuk edebiyatı dersi alma değişkenleri arasında anlamlı bir ilişki bulunmaktadır $(\mathrm{F}=23.67, \mathrm{p}<.05)$. Modele göre ilgili yordayıcılar resimleme özellikleri yeterlilik puanlarının toplam varyansının \%31'ini açıklamaktadır. Modele ilişkin standardize edilmiş beta $(\beta)$ katsayıları incelendiğinde okuma tutum $(\beta=.447, \mathrm{p}<.05)$ değiş̧keninin diğer değişkenlere oranla güçlü bir yordayıcı olduğu görülmektedir. Detaylı bilgi Tablo 10'da sunulmuştur.

Çoklu regresyon analiz sonuçlarına göre resimli hikâye kitaplarını fiziksel özellikleri açısından seçme yeterlilik puanları ile üniversitede okunan çocuk kitap sayısı, okuma tutum ve çocuk edebiyatı dersi alma değişkenleri arasında anlamlı bir ilişki bulunmaktadır $(\mathrm{F}=13.82, \mathrm{p}<.05)$. Modele göre ilgili yordayıcılar içerik özellikleri toplam varyansının \%21'ini açıklamaktadır. Modele ilişkin standardize edilmiş beta ( $\beta$ ) katsayıları incelendiğinde üniversitede okunan çocuk kitabı sayısı $(\beta=.245, \mathrm{p}<.05)$ değişkeninin diğer değişkenlere oranla daha güçlü bir 
yordayıcı olduğu görülmektedir. Haftalık kitap okuma süresi $(\beta=.033, p>.05)$ modelin anlamlı bir yordayıcısı değildir. Tablo 11'de detaylı bilgi sunulmuştur.

Tablo 11. Resimli Hikâye Kitaplarının Fiziksel Özellikleri Puanlarının Yordanmasına İlişkin Çoklu Regresyon Analiz Sonuçları

\begin{tabular}{lcccccc}
\hline Yordayıcılar & $\boldsymbol{B}$ & $\boldsymbol{\beta}$ & $\boldsymbol{t}$ & $\boldsymbol{p}$ & Tolerans & $\begin{array}{c}\text { Varyans arțS } \\
\text { değeri (VIF) }\end{array}$ \\
\hline Sabit & 36.367 & & 18.628 & .000 & & \\
$\begin{array}{l}\text { Üniversite eğitimi boyunca } \\
\text { okunan çocuk kitap sayısı }\end{array}$ & .152 & .245 & 3.300 & .001 & .687 & 1.456 \\
$\begin{array}{l}\text { Okuma Tutum } \\
\text { Haftalık kitap okuma }\end{array}$ & .071 & .208 & 2.821 & .005 & .700 & 1.429 \\
$\begin{array}{l}\text { süresi } \\
\text { Çocuk edebiyatı dersini } \\
\text { alıp almama }\end{array}$ & .001 & .033 & .442 & .659 & .674 & 1.483 \\
\hline
\end{tabular}

$R 2=.21$, Düzeltilmiş $R 2=.20, F(5,207)=13.82, p<.05$

\section{Tartışma ve Sonuç}

Bu çalışmada, okul öncesi öğretmen adaylarının kişisel okuma alışkanlıkları, tutum ve deneyimlerine göre resimli çocuk kitaplarını seçme yeterliliklerinin incelenmesi amaçlanmıştır. Araştırma bulguları incelendiğinde, öğretmen adaylarının haftalık kitap okuma süreleri 0 ile 250 dakika arasında değişmektedir. Öğretmen adaylarından 19'u hiç kitap okumadıklarını belirtmişlerdir. Öğretmen adaylarının okuma alışkanlıklarının düşük olduğu görülmektedir. Öğretmen adaylarının okuma alışkanlıklarını inceleyen önceki çalışmalarda da bu çalışma sonuçlarını destekleyen sonuçlara ulaşılmıştır (Esgin \& Karadağ, 2000; Geçgel \& Burgul, 2009; Odabaş vd., 2008; Saraçoğlu vd., 2010; Yılmaz, Köse, \& Korkut, 2009). Öğretmen adaylarının yıllık okudukları kitap sayısı ortalaması ise $6.21(\mathrm{SD}=2.90)$ adettir. Saraçoğlu vd. (2010) öğretmen adaylarının \%12.9'un hiç kitap okumadıklarını ve ayda ortalama okunan kitap sayısının iki olduğunu tespit etmişlerdir. Yılmaz vd. (2009) üniversite öğrencilerinin \%25'nin hiç kitap okumadıklarını belirtmiş̧lerdir. Öğretmen adaylarının okuma tutum puan ortalamaları incelendiğinde kriter olan 75 puanın sadece iki puan üstünde olduğu görülmektedir. Saraçoğlu, Yenice ve Karasakaloğlu (2009) öğretmen adaylarının okuma ilgilerinin orta düzeyde olduğunu tespit etmişlerdir. Dedeoğlu ve Ulusoy (2013) çalışmalarında öğretmen adaylarının okuma tutumlarının düşük-orta düzeyde olduğunu belirtmiş̧lerdir.

Öğretmen adaylarının \%52.1'i ailelerinin kendilerine çocukluklarında hiç kitap okumadığını belirtmişlerdir. Ailelerinin çocukluklarında kendilerine düzenli kitap okunduğu belirten öğretmen aday yüzdesi ise \%10.3'dür. Okul öncesi dönemde ailelerin çocuklarına kitap okuma alışkanlıklarını inceleyen çalışmalar da bu çalışmaya benzer sonuçlara ulaşmışlardır (Altun, 2013; Altun \& Tantekin Erden, 2015). Altun ve Tantekin Erden (2015) yürüttükleri çalışma sonuçlarına göre okul öncesi dönem çocuklarının \%33'üne aileleri haftalık 0-60 dakika arası kitap okumaktadır. Annelerin \%43'ünün ve babaların \%40'ının haftalık kitap okuma süreleri 0 ile 60 dakika arasındadır. $\mathrm{Bu}$ çalışma ve önceki çalışmaların bulguları ülkemizde okuma kültürünün zayıf olduğunu göstermektedir. Ülkemizde okuryazar oranı \%96.22'ye ulaşmasına rağmen (Türkiye İstatistik Kurumu (TUİK), 2016) düzenli kitap okuma alışkanlığı oranının çok düşük olduğu dikkat çekmektedir. Okuma alışkanlığı ailede kazanılmakta ve ebeveynler çocuklarına bu konuda rol model olmaktadır (Reese, Sparks, \& Leyva, 2010; Sénéchal, Lefevre, Thomas, \& Daley, 1998; Weigel, Martin, \& Bennett, 2006). Örneğin Polonyo'da 2001 yllında başlatılan kampanya (Cała Polska czyta dzieciom) ile ülke genelinde çocuklara kitap okuma seferberliği ilan edilmiş̧ir. Popüler sanatçılar, ünlü kişiler kampanyaya katılarak anaokullarını ziyaret etmiş ve çocuklara kitap okumuşlardır. Ayrıca, televizyon, radyo ve sosyal medya aracıllğılyla kampanya hakkında halka bilgi verilmiş ve bu yolla kitap okumaya ilişkin farkındalık yaratılmıştır (Lewandowicz-Nosal, 2017). Kampanyanın başarılı sonuçlarından sonra bu uygulama önce Çek Cumhuriyeti'nde daha sonra da tüm Avrupa'da (All of Europe Reads to Kids) yaygınlaştırılmıştır (OECD, 2012). Ülkemizde görülen okumaz-okuryazarlar olgusunun kırılmasında ilk görev zincirin ilk halkası olan aileye düştüğü görülmektedir. Çocuğun okula başlaması ile birlikte sınıfta 
oluşturulacak okuma kültürü, öğretmenin davranış ve tutumları da çocukların okuma alışkanlığı kazanmalarında önemli olduğu düşünülmektedir. Mevcut tablo değerlendirildiğinde, ülkemizde gelecek nesillere okuma alışkanlığının kazandırılması için aile ve okul boyutlarını kapsayan sistematik çalışmalara ve kampanyalara ihtiyaç duyulduğu görülmektedir.

Araştırma bulguları incelendiğinde, öğretmen adaylarının kişisel okuma alışkanlıkları, okuma tutumları, üniversite eğitimleri boyunca okudukları çocuk kitabı sayısı ve çocuk edebiyatı dersi almaları ile resimli hikâye kitabı seçme yeterlilikleri arasında anlamlı ilişki bulunmaktadır. Turan vd. (2017) çalışmalarında 3. sınıfta okuyan okul öncesi öğretmen adaylarının resimli hikâye kitabı seçme yeterlilikleri puanlarının 2. ve 4. sınıfta okuyan okul öncesi öğretmen adaylarına göre daha yüksek olduğunu tespit etmişlerdir. Ergün ve Gündüz (2011) 3. ve 4. sınıf okul öncesi öğretmen adaylarının çocuk kitaplarını değerlendirme ile ilgili görüşlerini karşılaştırdıkları çalışmalarında sınıf düzeyine göre fark bulamamışlardır. Bu çalışma kapsamında tüm sınıf düzeylerinden öğretmen adayları ile çalışılmıştır. Öğretmen adaylarının çocuk edebiyatı dersi alıp almama durumlarına göre karşılaştırma yapılmış ve dersi alanlar lehine anlamlı sonuç bulunmuştur. Çocuk edebiyatı dersi alan öğretmen adaylarının daha yüksek resimli hikâye kitabı seçme yeterlilikleri puanlarına sahip olmaları beklendik bir sonuçtur. Ders kapsamında öğretmen adayları resimli çocuk kitaplarında bulunması gereken özellikler hakkında teorik bilgiler edinmekte ve uygulamalar ile deneyim kazanmaktadır. Bu çalışmada odaklanılan asıl kısım çocuk edebiyatı dersi almanın yanında öğretmen adaylarının kişisel okuma alışkanlık, tutum ve deneyimleri ile resimli hikâye kitabı seçme yeterlilikleri arasında ilişkinin araştırılmasıdır. Araştırma bulgularına göre okuma tutumu yüksek, okuma alışkanlığı olan ve üniversite eğitimi boyunca daha çok çocuk kitabı okuyan öğretmen adayları daha yüksek resimli hikâye kitabı seçme yeterlilikleri puanlarına sahiptir. Öğretmen adayları okudukları çocuk kitapları ile hikâyelerde kullanılan üslup ve anlatım yöntemleri, ele alınan konular, resimleme teknikleri (suluboya, pastel, yağlı boya, dijital vb.), kitap dizayn ve tasarımı hakkında deneyim kazanmaktadırlar. Çocuk kitapları hakkında kazandıkları bu deneyimin resimli hikâye kitabı seçme yeterliliklerini desteklediği düşünülmektedir. Bu nedenle öğretmen adaylarının çocukların gelişim seviyelerine uygun kitap seçmelerinde çocuk edebiyatı alan yazınında yayınlanan resimli hikâye takip etmeleri ve okumalarının önemli olduğu söylenebilir.

Öğretmen adaylarının okuma alışkanlık ve tutumları arasında güçlü ilişki bulunmaktadır. Bununla birlikte, yapılan çalışmalar kitap okuma alışkanlığ ve okuma tutumu ile eleştirel düşünme becerileri arasında ilişki olduğunu göstermektedir (Gündüz, 2015; Karasakaloğlu, Saraçoğlu, \& Yılmaz-Özelçi, 2012; Koçak, Kurtlu, Ulaş, \& Epçaçan, 2015). Karasakaloğlu vd. (2012) Türkçe öğretmeni adaylarının eleştirel düşünme ve üst biliş yeterlilik puanları kitap okuma alışkanlıklarına göre farklılaştığını tespit etmişlerdir. Çalışma bulguları yılda 21 ve üstü kitap okuyan öğretmen adaylarının, yılda 1-5 arası ve 6- 20 arası kitap okuyanlara oranla daha yüksek eleştirel düşünme ve üst biliş yeterlilik puanlarına sahip olduğunu göstermektedir. Gündüz (2015) üniversite 1. Sınıf öğrencilerinin kitap okuma alışkanlıkları ile eleştirel düşünme becerileri arasında pozitif yönde güçlü bir ilişki olduğunu tespit etmiştir. Güven ve Aktaş (2014) 627 5. sınıf öğrencisi ile yürüttükleri çalışma sonucuna göre günlük okuma süreleri yüksek olan öğrencilerin görsel okuma ve eleştirel düşünme beceri puanları da yüksektir. Görsel okuma becerisi ile eleştirel düşünme becerisi arasında pozitif yönde orta düzeyde (anlamlı bir ilişki tespit etmişlerdir. Bu sonuçlardan yola çıkarak, öğretmen adaylarının okuma alışkanlıkları hem çocuk kitapları hakkında deneyimlerini artırarak doğrudan hem de eleştirel düşünme ve üst biliş gibi bilişsel gelişimlerini destekleyerek dolaylı olarak resimli hikâye seçme yeterliliklerine katkı sağlayabileceği düşünülmektedir. İleride yapılacak çalışmalarda ilgili değişkenlerin yapısal eşitlik modellemesi kullanılarak değişkenler arasındaki ilişkiler daha net bir şekilde tespit edebilirler. $\mathrm{Bu}$ bağlamda, yürütülen bu çalışmanın öğretmen adaylarının resimli çocuk kitabı seçme yeterlilikleriyle ilişkili olabilecek farklı değişkenleri ele alması bakımından önemli olduğu düşünülmektedir. Öğretmen adaylarının ve öğretmenlerin resimli çocuk kitabı seçme yeterliliklerini ve bu yeterlilikleri etkileyen faktörleri belirlemeyi amaçlayan araştırmalara alanda ihtiyaç duyulmaktadır. 


\section{References}

Altun, D. (2016) A multilevel analysis of home and classroom literacy environment in relations to preschoolers' early literacy development (Doctoral dissertation). Middle East Technical University, Ankara, Turkey

Altun, D. (2013). An investigation of the relationship between preschoolers' reading attitudes and home literacy environment (Master's thesis). Middle East Technical University, Turkey.

Altun, D., \& Tantekin-Erden, F. (2015). Okuryazarlık süreci açısından ev-içi okuryazarlık ortamı: çocukların ilkokula başlamadan önce ev-içi okuryazarlık deneyimlerinin incelenmesi [Home literacy envronment regarding literacy development process: an examination of children's home literacy environment before entering primary school 14. Uluslararası Katılımlı Sınıf Öğretmenliği Sempozyumu (USOS), Bartın, Türkiye.

Arizpe, E., \& Styles, M. (2004). Children reading pictures: Interpreting visual texts. London: Routledge.

Baccus, A. A. (2004). Urban fourth and fifth grade teachers' reading attitudes and efficacy beliefs: Relationships to reading instruction and to students' attitudes and efficacy beliefs (Doctoral dissertation). Retrieved from ProQuest Dissertation and Theses database. (UMI No. 3123161)

Bayram, S. (2001). Türkiye'de kitap okuma alışkanlı̆̆l [The reading habits in Turkey]. İstanbul: İstanbul Ticaret Odas1.

Bus, A. G., Van Ijzendoorn, M. H., \& Pellegrini, A. D.(1995). Joint book reading makes for success in learning to read: A meta-analysis on intergenerational transmission of literacy. Review of educational research, 65(1), $1-21$.

Çatalcı -Soyer, A. (2009). Okul öncesi dönem çocuk hikâye kitapları: Stereotipler ve kimlikler [Storybooks of the preschool kids: sterotypes and identities]. Mehmet Akif Ersoy Üniversitesi Sosyal Bilimler Enstitüsü Dergisi, (1), 13-27.

Dağlığlu, H. E., \& Çakmak Çamlıbel, Ö. (2009). Okul öncesi çocuklarına yönelik yayınlanan hikâye kitaplarının şiddet ve korku öğeleri açısından incelenmesi [Examination of story books produced towards preschool children regarding elements of violence and horror]. Türk Kütüphaneciliği, 23(3), 510-534.

Dedeoğlu, H., \& Ulusoy, M. (2013). Sınıf öğretmeni adaylarının okuma tutumları [Classroom pre-service teachers' reading attitudes]. Okuma Yazma Eğitimi Araştırmaları, 1(2), 80-88.

Ergün, M., \& Gündüz, A. (2011). Okul öncesi öğretmen adaylarının okul öncesi çocuk kitaplarını değerlendirmesi [Pre-service preschool teachers' evaluations of children's book]. Journal of Educational and Instructional Studies in the World, 1(1), 23-29.

Esgin, A., \& Karadağ, Ö. (2000). Üniversite öğrencilerinin okuma alışkanlığı [Reading habits of university students]. Popüler Bilim, 7(82), 19-23.

Evans, M. D. R., Kelley, J., \& Sikora, J. (2014). Scholarly culture and academic performance in 42 nations. Social Forces, 92(4), 1573-1605.

Evans, M. D., Kelley, J., Sikora, J., \& Treiman, D. J. (2010). Family scholarly culture and educational success: Books and schooling in 27 nations. Research in Social Stratification and Mobility, 28(2), 171-197.

Flack, Z., Field, A., \& Horst, J. (2017). The effects of shared storybook reading on word learning: a metaanalysis. Developmental Psychology. Retrieved from http://sro.sussex.ac.uk/72697/1/_smbhome. uscs.susx.ac.uk_ellenaj_Desktop_SRO_after\%20august_Meta-Accepted-Version.pdf

Geçgel, H., \& Burgul, F. (2009). Eğitim Fakültesi Öğrencilerinin Okuma İlgi Alanları (Çanakkale Örneği) [Interested reading area of education faculty students (Çanakkale case)]. Tübav Bilim Dergisi, 2(3), 341-353.

Gönen, M., Burçak, F., Uysal, H., \& Bediz, E. (2017). 0-3 yaş dönemi kitapları [Book for 0-3 ages]. In M. Gönen (Ed.), Çocuk edebiyatı [Children's literature] (pp. 77-92). Ankara: Eğiten Kitap. 
Gönen, M., Uludă̆, G., Fındık Tanrıbuyurdu, E., \& Tüfekçi, E. (2014). 0-3 yaş çocuklarına yönelik resimli çocuk kitaplarının özelliklerinin incelenmesi [The examination of children's picture books' features for 0-3year-olds]. Hacettepe Üniversitesi Ĕ̈itim Fakültesi Dergisi, 29(1), 126-139.

Guijarro, A. J. M. (2014). A multimodal analysis of picture books for children: A systemic functional approach . London: Equinox Publishing.

Gündüz, B. (2015). Üniversite 1 sınıf öğrencilerinin kitap okuma alışkanlıkları ve eleştirel okuma becerileri üzerine bir durum çalışması [A study on university freshmen's reading habits and critical reading skills: a case study ] (Master's thesis), Bilkent University, Ankara, Turkey.

Gür, T. (2014). Öğretmen Adaylarının Okuma ve Boş Zaman Değerlendirme Alışkanlıkları [Reading and leisure times activity habits of preservice teachers]. Zeitschrift für die Welt der Türken [Journal of World of Turks], 6(1), 161-180.

Güven, M., \& Aktaş, B. Ç. (2014). Eleştirel okuma ve görsel okuma arasındaki ilişki [The relationship between critical reading and visual reading].Uluslararası Ë̆itim Programları ve Öğretim Çalışmaları Dergisi, 3(6), $31-45$.

Hepburn, E., Egan, B., \& Flynn, N. (2010). Vocabulary acquisition in young children: The role of the story. Journal of Early Childhood Literacy, 10(2), 159-182.

Huck, C. S. (1973). Strategies for improving interest and appreciation in literature. In A. Burns, P. C., \& Schell, L. M (Eds.) Elementary school language arts. Chicago: Rand McNally.

Karaşahin, M. (2009). İlköğretim ve ortaöğretim okullarında görev yapan öğretmenlerin okuma kültürlerinin değerlendirilmesi. [The evaluation of primary and secondary grade teachers reading cultures]. The Ministry of National Education Research Report. Retrieved from http://yegitek.meb.gov.tr/ tamamlanan/ ogretmenlerin_okuma_kulturleri.pdf

Karasakaloğlu, N., Saracaloğlu, S. \& Yılmaz-Özelçi, S. (2012). Türkçe öğretmeni adaylarının okuma stratejileri, eleştirel düşünme tutumları ve üst bilişsel yeterlilikleri [Turkish prospective teachers' reading strategies, critical thinking attitudes and metacognitive competencies]. Ahi Evran Üniversitesi Kirşehir Eğitim Fakültesi Dergisi (KEFAD), 13(1), 207-221.

Kırmızi, F. S. (2011). The relationship between reading comprehension strategies and reading attitudes. Education 3-13, 39(3), 289-303.

Kiefer, B. Z., Hepler, S. I., \& Hickman, J. (2007). Charlotte Huck's children's literature. McGraw-Hill Companies

Koçak, B., Kurtlu, Y., Ulaş, H., \& Epçaçan, C. (2015). Sınıf öğretmeni adaylarının eleştirel düşünme düzeyleri ve okumaya yönelik tutumları arasındaki ilişki [Examining of the elementary class teachers' critical thinking levels and their attitudes towards reading]. Ekev Akademi Dergisi, 61(61), 211-228.

Konan, N. (2013). İlköğretim okulu yöneticilerinin okuma alışkanlıkları [Reading habits of elementary school manager]. Kuram ve Uygulamada Eğitim Yönetimi Dergisi, 19(1), 31-59.

Kuş, Z., \& Türkyılmaz, M. (2010). Sosyal bilgiler ve Türkçe öğretmeni adaylarının okuma durumları:(İlgi, alışkanlık ve okuma stratejilerini kullanım düzeyleri) [Reading statuses of social studies and Turkish language teacher candidates: (Their attention, habits and levels of using reading strategies)]. Türk Kütüphaneciliği, 24(1), 11-32.

Lewandowicz-Nosal, G. (2017). The joy of reading-reading aloud. A complex partnership. Retrieved from http://library.ifla.org/1791/1/138-lewandowicz-nosal-en.pdf

Mavi, H. F., \& Çetin, B. (2009). Beden Eğitimi öğretmen adaylarının kitap okumaya ilişkin görüş ve tutumlarının değerlendirilmesi [The evaluation of pre-service physical education teachers attitutes and views on reading]. Celal Bayar Üniversitesi. Beden Eğitimi ve Spor Bilimleri Dergisi, 4(1), 1-11. 
McKenna, M. C. (1994). Toward a model of reading attitude acquisition. In E. H. Crammer \& M. Castle (Eds.), Fostering the love of reading: The affective domain in reading education. (pp. 18-40). Newark, DE: International Reading Association.

Mckenna, M. C., Kear, D. J., \& Elisworth, R. A. (1995). Children's attitudes toward reading:A national survey. Reading Research Quarterly, 30(4), 934-956.

Mikulecky, L. J. (1976). The developing, field testing, and initial norming of a secondary/adult level reading attitude measure that is behaviorally oriented and based on Krathwohl's taxonomy of the affective domain. (Doctoral dissertation), The University of Wisconsin-Madison, USA.

Odabaş, H., Odabaş, Y., \& Polat, C. (2008). Üniversite öğrencilerinin okuma alışkanlığı: Ankara Üniversitesi örneği [Reading habit of university students: The model of Ankara University]. Bilgi Dünyasl, 9(2), 431-465.

OECD (2012), Let's read them a story! The parent factor in education, PISA, OECD Publishing. Retrieved from http://dx.doi.org/ 10.1787 /97892 64176232-en

Pallant, J. (2010). SPSS survival manual: A step by step guide to data analysis using SPSS . Buckingham: Open University Press.

Painter, C., Martin, J. R., \& Unsworth, L. (2013). Reading visual narratives. London: Equinox.

Petscher, Y. (2010). A meta-analysis of the relationship between student attitudes towards reading and achievement in reading. Journal of Research in Reading, 33(4), 335-355.

Progress in International Reading Literacy Study (PIRLS). (2001). PIRLS 2001 International Report. Retrieved from http://timss.bc.edu/ pirls2001i/pdf/p1_ir_book.pdf.

Reese, E., Sparks, A., \& Leyva, D. (2010). A review of parent interventions for preschool children's language and emergent literacy. Journal of Early Childhood Literacy, 10(1), 97-117.

Richardson, J. S., Morgan, R. F., \& Fleener, C. (2009). Reading to learn in the content areas (7th ed.). CA: Wadsworth Cengage Learning.

Sağlam, M., Suna, Ç., \& Çengelci, T. (2007). Sınıf öğretmenliği ile diğer öğretmenlik programları öğrencilerinin okuma alışkanlığı düzeylerinin karşılaştırılması [Comparing levels of reading habits of pre-service primary teaching with other teaching programs]. VI. Ulusal Sınıf Öğretmenliği Sempozyumu, 27-29.

Sallabas, M. E. (2008). İlköğretim 8. sınıf öğrencilerinin okumaya yönelik tutumları ve okuduğunu anlama becerileri arasındaki ilişki [Relationship between 8th grade secondary school students' reading attitudes and reading comprehension skills]. Inonu University Journal of the Faculty of Education 9(16), 141-155.

Saracaloğlu, A. S., Karasakaloğlu, N., \& Aslantürk, E. (2010). Sınıf öğretmeni adaylarının okuma ilgi ve alışkanlıklarının karşılaştırılması Adnan Menderes ve Uludağ Üniversiteleri örneği [Comparison of the candidate elementary teachers' reading interests and reading habits: Adnan Menderes and Uludağ University case]. Çukurova Üniversitesi Sosyal Bilimler Enstitüsü Dergisi, 19(3), 457-480.

Saracaloğlu, A. S., Yenice, N., \& Karasakaloğlu, N. (2009). Öğretmen adaylarının iletişim ve problem çözme becerileri ile okuma ilgi ve alışkanlıkları arasındaki ilişki [The relationship between communication and problem solving skills and reading interest and habits of candidate teachers]. Yüzüncü Yıl Üniversitesi Ĕgitim Fakültesi Dergisi, 6(2), 187-206.

Sénéchal, M., Lefevre, J. A., Thomas, E. M., \& Daley, K. E. (1998). Differential effects of home literacy experiences on the development of oral and written language. Reading Research Quarterly, 33(1), 96-116.

Şengül-Bircan, T. (2017). Tarih Öğretmeni Adaylarının Okuma Alışkanlıkları Üzerine Bir İnceleme [A study on the reading habit of history teacher candidates]. Zeitschrift für die Welt der Türken/Journal of World of Turks, 9(1), 25-40.

Smith, M. W., Brady, J. P., \& Anastasopoulos, L. (2008). User's guide to the early language \& literacy classroom observation Pre-K tool (ELLCO Pre-K). Baltimore: Brookes Publishing. 
Sonleitner, C.L. (2005). Metacognitive strategy use and its effect on college biology students' attitude toward reading in the content area (Master's thesis). Available from ProQuest Dissertation and Theses database. (UMI No. 1431108).

Tabachnick, B. G., \& Fidell, L. S. (2007). Using multivariate analysis. Boston: Pearson.

Turan, F., Gönen, M., \& Aydos, E. H. (2017). Okul öncesi öğretmen adaylarının resimli öykü kitaplarını seçme konusunda yeterlik düzeyleri ve kendi yeterliklerine ilişkin algılarının incelenmesi [Examination of level of competence in choosing picture story books and perception of self competence of early childhood education teacher candidates] Abant İzzet Baysal Üniversitesi Ĕ̈itim Fakültesi Dergisi, 17(1), 400-422.

Türkiye İstatistik Kurumu (TUIK) (2016). Key indicators. Retrieved from http://www.tuik.gov.tr/ PreTablo.do?alt_id=1018

Ulusoy, M., \& Altun, D. (2016). Preliterate preschoolers' oral explanations and visual narratives in response to picture books. Paper presented at Omep European Conference, Canterbury, England.

Ulusoy, M., \& Altun, D. (2017). Okul öncesi öğretmen adaylarının çocuk edebiyatı ve resimli çocuk kitapları ile ilgili metaforlarl [Pre-service preschool teachers' metaphors about children's literature and children's picture books]. Paper presented at International Conference on Quality in Higher Education (ICQH), Sakarya, Turkey.

Ural, S. (2015). Okul öncesi çocuk kitaplarının tanımı [Definition of pre-school children's books].Mübeccel Gönen (Ed.), Çocuk edebiyatı [Children's literature]. Ankara: Eğiten Kitap.

Uzmen, S., \& Mağden, D. (2002). Okulöncesi eğitim kurumlarına devam eden altı yaş çocuklarının prososyal davranışlarının resimli çocuk kitapları ile desteklenmesi [Enhancing six year old preschool children's prosocial behaviors by using picture books]. M. ̈̈. Atatürk Ĕ̆itim Fakültesi Eğitim Bilimleri Dergisi, 15, 193-212.

Warmack, W. L. (2007). Elementary education pre-service teachers' attitudes toward reading. (Doctoral Dissertation). Auburn University, Alabama, The United States.

Weigel, D.J., Martin, S.S., \& Bennett, K.K. (2006). Mothers' literacy beliefs: Connections with the homeliteracy environment and pre-school children's literacy development. Journal of Early Childhood Literacy, 6(2), 191-211.

Veziroğlu, M., \& Gönen, M. (2012). Resimli çocuk kitaplarının MEB Okul Öncesi Eğitim Programı'ndaki kazanımlara uygunluğunun incelenmesi [Review of the eligibility of picture books to the acquisition of the preschool education program of the Ministry of National Education]. Eğitim ve Bilim, 37(163), 226-238.

Yılmaz, B. (2002). Ankara'daki ilköğretim öğretmenlerinin okuma ve halk kütüphanesi kullanma alışkanlıkları üzerine bir araştırma [A research on reading and public library use habits of the primary school teachers in Ankara]. Türk Kütüphaneciliği, 16(4), 441-460.

Yılmaz, B., Köse, E., \& Korkut, Ş. (2009). Hacettepe Üniversitesi ve Bilkent Üniversitesi öğrencilerinin okuma alışkanlıkları üzerine bir araştırma [A research on reading habits of Hacettepe University and Bilkent University students]. Türk Kütüphaneciliği, 23(1), 22-51.

Yükselen, A. İ. (2017). Yaş gruplarına göre çocuk kitapları [Children's book by age group]. In M. Gönen (Ed.), Çocuk edebiyatı [Children's literature] (pp. 57- 76), Ankara: Eğiten Kitap. 